\title{
CONSTITUIÇÃO, DEMOCRACIA E SUPREMACIA JUDICIAL: DIREITO E POLÍTICA NO BRASIL CONTEMPORÂNEO
}

\author{
Luís Roberto Barroso ${ }^{1-2}$
}

\begin{abstract}
RESUMO
O presente trabalho se propõe a analisar as relações entre o direito e a política, no contexto atual de ascensão institucional do Poder Judiciário, em que se destacam a crescente judicialização de questões sociais, morais e políticas, bem como um certo grau de ativismo judicial. O estudo passará pela análise da concepção tradicional, de pretensa separação absoluta entre os domínios, para, em seguida, revelar o modelo real, em que se verifica a convivência e influência recíprocas entre direito e política, inclusive com o reconhecimento de que diversos fatores extrajurídicos são capazes de repercutir em maior ou menor medida sobre um julgamento. Com isso, pretende-se estabelecer parâmetros para a compreensão adequada da relação entre direito e política, de modo a permitir o controle da legitimidade e da razoabilidade dessa interação, em busca do equilíbrio desejável em uma sociedade democrática entre razão e vontade.
\end{abstract}

Palavras-chave: Direito. Política. Judicialização. Ativismo judicial.Parâmetros

\begin{abstract}
This article focuses on the relations between law and politics, in the context of the institutional rise of the Judiciary, which has as its characteristics the increasing judicialization of social, moral and political issues, accompanied by a certain degree of judicial activism. In its initial part, the article describes the traditional conception of absolute separation between law and politics and criticizes the old formalist view, still adopted by many scholars, that try to deny the mutual influence of one over the other. In its final part, the articles discusses a set of non-legal factors that can affect the judicial decision-making process. The main purpose of the text is to provide elements that will permit the control of the legitimacy and rationality of the interaction between law and politics, in order to strike the indispensable balance in democratic societies between reason and will

\footnotetext{
${ }^{1}$ Professor titular de direito constitucional da Universidade do Estado do Rio de Janeiro - UERJ. Professor visitante da Universidade de Brasília - UnB, da Universidade de Poitiers, França e da Universidade de Wroclaw, Polônia. Mestre em direito pela Universidade de Yale. Doutor e livre-docente pela UERJ. E-mail: lrbarroso@1rbarroso.com.br

${ }^{2}$ Parte da pesquisa para este trabalho foi realizada na Universidade de Harvard - na Faculdade de Direito e na Kennedy School of Government. Sou grato à instituição e, especialmente, ao Professor Filipe Campante, pela acolhida que me deram como pesquisador visitante, nos meses de julho de 2009 e janeiro de 2010. E à Renata Campante e ao Paulo Barrozo, pela amizade, atenção e muitas dicas que tornaram a pesquisa e a vida mais fáceis. Sou grato, também, a Ana Paula de Barcellos e a Thiago Magalhães Pires, pela leitura atenta e comentários importantes. E a Daniel Sarmento por uma boa sugestão, que ficará para a próxima.
} 
Keywords: Law. Politics. Judicialization. Judicial activism. Standards

\section{INTRODUÇÃo}

O estudo que se segue está dividido em três partes. Na primeira, narra-se a ascensão institucional do Judiciário nos últimos anos, no Brasil e no mundo. São apresentados, assim, os fenômenos da jurisdição constitucional, da judicialização e do ativismo judicial, bem como as críticas à expansão do Judiciário na vida brasileira. O tópico se encerra com a demonstração da importância e dos limites da jurisdição constitucional nas democracias contemporâneas. A segunda parte é dedicada à concepção tradicional das relações entre direito e política, fundada na separação plena entre os dois domínios ${ }^{3}$. A Constituição faz a interface entre o universo político e o jurídico, instituindo o Estado de direito, os poderes constituídos e fazendo a distinção entre legislar, administrar e julgar. A atuação de juízes e tribunais é preservada do contágio político por meio da independência do Judiciário em relação aos demais Poderes e por sua vinculação ao direito, que constitui um mundo autônomo, tanto do ponto de vista normativo quanto doutrinário. Essa visão, inspirada pelo formalismo jurídico, apresenta inúmeras insuficiências teóricas e enfrenta boa quantidade de objeções, em uma era marcada pela complexidade da interpretação jurídica e por forte interação do Judiciário com outros atores políticos relevantes.

A terceira parte introduz uma questão relativamente nova no debate jurídico brasileiro: o modelo real das relações entre direito e política. Uma análise sobre o que de fato ocorre no exercício da prestação jurisdicional e na interpretação das normas jurídicas, e não um discurso convencional sobre como elas deveriam ser. Trata-se de uma especulação acerca dos elementos e circunstâncias que motivam e influenciam um juiz, para além da boa aplicação do direito. Com isso, procura-se superar a persistente negação com que os juristas tradicionalmente lidam com o tema, proclamando uma independência que não é desse mundo. $\mathrm{Na}$ construção do argumento, examinam-se algumas hipóteses que produzem os chamados casos difíceis, que exigem a atuação criativa de juízes e tribunais; e faz-se, igualmente, uma reflexão acerca dos diferentes métodos de interpretação e sua utilização em função do

\footnotetext{
${ }^{3}$ É da tradição da doutrina brasileira grafar a palavra direito com letra maiúscula, em certos contextos. Nesse trabalho, todavia, em que o termo é empregado em sua relação com a política, o uso da maiúscula poderia passar a impressão de uma hierarquização entre os dois domínios, o que não é minha intenção. Restaria a alternativa de grafar política com maiúscula. Mas também não me pareceu ser o caso.
} 
resultado a que se quer chegar. Por fim, são identificados diversos fatores extrajurídicos relevantes, capazes de repercutir em maior ou menor medida sobre um julgamento, como os valores pessoais do juiz, as relações do Judiciário com outros atores políticos e a opinião pública, dentre outros.

Entre o ceticismo do realismo jurídico e da teoria crítica, que equiparam o direito ao voluntarismo e à política, e a visão idealizada do formalismo jurídico, com sua crença na existência de um muro divisório entre ambos, o presente estudo irá demonstrar o que já se afigurava intuitivo: no mundo real, não vigora nem a equiparação nem a separação plena. $\mathrm{Na}$ concretização das normas jurídicas, sobretudo as normas constitucionais, direito e política convivem e se influenciam reciprocamente, numa interação que tem complexidades, sutilezas e variações ${ }^{4}$. Em múltiplas hipóteses, não poderá o intérprete fundar-se em elementos de pura razão e objetividade, como é a ambição do direito. Nem por isso, recairá na discricionariedade e na subjetividade, presentes nas decisões políticas. Entre os dois extremos, existe um espaço em que a vontade é exercida dentro de parâmetros de razoabilidade e de legitimidade, que podem ser controlados pela comunidade jurídica e pela sociedade. Vale dizer: o que se quer é balizado pelo que se pode e pelo que se deve fazer.

\section{Parte I}

\section{A ASCENSÃO INSTITUCIONAL DO JUDICIÁRIO ${ }^{5}$}

\section{A JURISDIÇÃO CONSTITUCIONAL}

O Estado constitucional de direito se consolida, na Europa continental, a partir do final da II Guerra Mundial. Até então, vigorava um modelo identificado, por vezes, como Estado legislativo de direito ${ }^{6}$. Nele, a Constituição era compreendida, essencialmente, como um documento político, cujas normas não eram aplicáveis diretamente, ficando na dependência de desenvolvimento pelo legislador ou pelo administrador. Tampouco existia o controle de constitucionalidade das leis pelo Judiciário - ou, onde existia, era tímido e pouco relevante.

\footnotetext{
${ }^{4}$ O termo "política" é utilizado nesse trabalho em uma acepção ampla, que transcende uma conotação partidária ou de luta pelo poder. Na acepção aqui empregada, "política" abrange qualquer influência extrajurídica capaz de afetar o resultado de um julgamento.

${ }^{5}$ A Parte I deste trabalho, especialmente os capítulos II e III, beneficia-se da pesquisa e de algumas passagens de texto anterior de minha autoria, "Judicialização, ativismo judicial e legitimidade democrática", publicado na Revista de direito do Estado, Salvador, jan./mar. 2009, n. 13, p. 71.

6 V. FERRAJOLI, Luigi. "Pasado y futuro Del Estado de derecho". In: CARBONELL, Miguel (org.). Neoconstitucionalismo(s). Madrid: Trotta, 2003, p. 14-17; e ZAGREBELSKY, Gustavo. El derecho dúctil: ley, derechos, justicia. 6. ed. Madrid: Trotta, 2005, p. 21-41.
} 
Nesse ambiente, vigorava a centralidade da lei e a supremacia do parlamento. No Estado constitucional de direito, a Constituição passa a valer como norma jurídica. A partir daí, ela não apenas disciplina o modo de produção das leis e atos normativos, como estabelece determinados limites para o seu conteúdo, além de impor deveres de atuação ao Estado. Nesse novo modelo, vigora a centralidade da Constituição e a supremacia judicial, como tal entendida a primazia de um tribunal constitucional ou suprema corte na interpretação final e vinculante das normas constitucionais.

A expressão jurisdição constitucional designa a interpretação e aplicação da Constituição por órgãos judiciais. No caso brasileiro, essa competência é exercida por todos os juízes e tribunais, situando-se o Supremo Tribunal Federal no topo do sistema. A jurisdição constitucional compreende duas atuações particulares. A primeira, de aplicação direta da Constituição às situações nela contempladas. Por exemplo, o reconhecimento de que determinada competência é do Estado, não da União; ou do direito do contribuinte a uma imunidade tributária; ou do direito à liberdade de expressão, sem censura ou licença prévia. A segunda atuação envolve a aplicação indireta da Constituição, que se dá quando o intérprete a utiliza como parâmetro para aferir a validade de uma norma infraconstitucional (controle de constitucionalidade) ou para atribuir a ela o melhor sentido, em meio a diferentes possibilidades (interpretação conforme a Constituição). Em suma: a jurisdição constitucional compreende o poder exercido por juízes e tribunais na aplicação direta da Constituição, no desempenho do controle de constitucionalidade das leis e dos atos do Poder Público em geral e na interpretação do ordenamento infraconstitucional conforme a Constituição.

\section{A JUDICIALIZAÇÃO DA POLÍTICA E DAS RELAÇÕES SOCIAIS ${ }^{7}$}

\footnotetext{
${ }^{7}$ Sobre o tema, v. o trabalho pioneiro de VIANNA, Luiz Werneck; CARVALHO, Maria Alice Resende de; MELO, Manuel Palacios Cunha; BURGOS, Marcelo Baumann. A judicialização da política e das relações sociais no Brasil. Rio de Janeiro: Renavan, 1999. V. tb., CITTADINO, Giselle. "Judicialização da política, constitucionalismo democrático e separação de Poderes". In: VIANNA, Luiz Werneck (org.). A democracia e os três Poderes no Brasil. Belo Horizonte: UFMG, 2002. Vejam-se, ainda: VIANNA, Luiz Werneck; BURGOS, Marcelo Baumann; SALLES, Paula Martins. Dezessete anos de judicialização da política. Tempo Social, São Paulo, nov. 2007, v. 19, n. 2, p. 39; CARVALHO, Ernani. Judicialização da política no Brasil: controlo de constitucionalidade e racionalidade política. Análise Social, Lisboa, 2009, v. 44, n.191, p. 315; CARVALHO, Ernani Rodrigues de. Em busca da judicialização da política no Brasil: apontamentos para uma nova abordagem. Revista de Sociologia Política, São Paulo, nov. 2004, n. 23, p. 115; ARANTES, Rogério Bastos. "Judiciário: entre a justiça e a política". In: AVELAR, L. \& CINTRA, A. O. (orgs.), Sistema político brasileiro : uma introdução. 2. ed. Rio de Janeiro: Konrad-Adenauer-Stiftung; São Paulo: Editora Unesp, 2007; Constitutionalism, the expansion of justice and the judicialization of politics in Brazil. In: SIEDER, Rachel; SCHJOLDEN, Line; ANGELL, Alan (Org.). The Judicialization of Politics in Latin America. 1. ed. New York: Palgrave Macmillan, 2005, p. 231-262; LIMA, Martonio Mont'Alverne Barreto. Judicialização da política e comissões parlamentares de inquérito - um problema da teoria constitucional da democracia. Revista Jurídica da FIC, Fortaleza, 2006, v. 4, n. 7, p. 9; ROS, Luciano da. Tribunais como árbitros ou como instrumentos de
} 
Judicialização significa que questões relevantes do ponto de vista político, social ou moral estão sendo decididas, em caráter final, pelo Poder Judiciário. Trata-se, como intuitivo, de uma transferência de poder para as instituições judiciais, em detrimento das instâncias políticas tradicionais, que são o Legislativo e o Executivo. Essa expansão da jurisdição e do discurso jurídico constitui uma mudança drástica no modo de se pensar e de se praticar o direito no mundo romano-germânico ${ }^{8}$. Fruto da conjugação de circunstâncias diversas ${ }^{9}$, o fenômeno é mundial, alcançando até mesmo países que tradicionalmente seguiram o modelo inglês - a chamada democracia ao estilo de Westminster -, com soberania parlamentar e ausência de controle de constitucionalidade ${ }^{10}$. Exemplos numerosos e inequívocos de judicialização ilustram a fluidez da fronteira entre política e justiça no mundo contemporâneo, documentando que nem sempre é nítida a linha que divide a criação e a interpretação do direito. Os precedentes podem ser encontrados em países diversos e distantes entre si, como Canadá $^{11}$, Estados Unidos ${ }^{12}$, Israel $^{13}$, Turquia ${ }^{14}$, Hungria ${ }^{15}$ e Coreia ${ }^{16}$, dentre muitos outros. No início de 2010, uma decisão do Conselho Constitucional francês e outra da Suprema Corte

oposição: uma tipologia a partir dos estudos recentes sobre judicialização da política com aplicação ao caso brasileiro contemporâneo, Direito, Estado e Sociedade, jul./dez. 2007, n. 31, p. 86; AGUIAR; Thais Florencio de. A judicialização da política ou o rearranjo da democracia liberal. Ponto e Vírgula, São Paulo, 2007, n. 2, p. 142 .

${ }^{8}$ V. SWEET, Alec Stone. Governing with judges: constitutional polítics in Europe. Oxford: Oxford University Press, 2000, p. 35-36 e 130. A visão prevalecente nas democracias parlamentares tradicionais de ser necessário evitar um "governo de juízes", reservando ao Judiciário apenas uma atuação como legislador negativo, já não corresponde à prática política atual. Tal compreensão da separação de Poderes encontra-se em "crise profunda" na Europa continental.

9 Para uma análise das condições para o surgimento e consolidação da judicialização, v. TATE, C. Neal; VALLINDER, Torbjörn (eds.). The global expansion of judicial Power. New York: New York University Press, 1995, p. 117.

${ }^{10}$ V. HIRSCHL, Ran. The new constitutionalism and the judicialization of pure politics worldwide. Fordham Law Review. 2006-2007, v. 75, n. 2, p. 721. A referência envolve países como Canadá, Israel, Nova Zelândia e o próprio Reino Unido.

${ }^{11}$ Decisão da Suprema Corte sobre a constitucionalidade de os Estados Unidos fazerem testes com mísseis em solo canadense. Este exemplo e os seguintes vêm descritos em maior detalhe em HIRSCHL, Ran. The judicialization of polítics. In: WHITTINGTON, Keith E.; KELEMEN, R. Daniel; CALDEIRA, Gregory A. (eds.), The Oxford handbook of law and politics. Oxford: Oxford University Press, 2008, p. 124-125.

${ }^{12}$ Decisão da Suprema Corte que definiu a eleição de 2000, em Bush v. Gore.

13 Decisão da Suprema Corte sobre a compatibilidade, com a Constituição e com os atos internacionais, da construção de um muro na fronteira com o território palestino.

${ }^{14}$ Decisões da Suprema Corte destinadas a preservar o Estado laico contra o avanço do fundamentalismo islâmico.

15 Decisão da Corte Constitucional sobre a validade de plano econômico de grande repercussão sobre a sociedade.

${ }^{16}$ Decisão da Corte Constitucional restituindo o mandato de presidente destituído por impeachment. 
americana produziram controvérsia e a reação política dos dois presidentes ${ }^{17}$. Na América Latina $^{18}$, o caso da Colômbia é um dos mais significativos ${ }^{19}$.

Há causas de naturezas diversas para o fenômeno. A primeira delas é o reconhecimento da importância de um Judiciário forte e independente, como elemento essencial para as democracias modernas. Como consequência, operou-se uma vertiginosa ascensão institucional de juízes e tribunais, assim na Europa como em países da América Latina, particularmente no Brasil. A segunda causa envolve certa desilusão com a política majoritária, em razão da crise de representatividade e de funcionalidade dos parlamentos em geral. Há uma terceira: atores políticos, muitas vezes, preferem que o Judiciário seja a instância decisória de certas questões polêmicas, em relação às quais exista desacordo moral razoável na sociedade. Com isso, evitam o próprio desgaste na deliberação de temas divisivos, como uniões homoafotetivas, interrupção de gestação ou demarcação de terras indígenas ${ }^{20}$. No Brasil, o fenômeno assumiu proporção ainda maior, em razão da constitucionalização abrangente e analítica - constitucionalizar é, em última análise, retirar um tema do debate político e trazê-lo para o universo das pretensões judicializáveis - e do sistema de controle de constitucionalidade vigente entre nós, em que é amplo o acesso ao Supremo Tribunal Federal por via de ações diretas.

\footnotetext{
${ }^{17} \mathrm{Na}$ França, foi anulado o imposto do carbono, que incidiria sobre o consumo e a emissão de gases poluentes, com forte reação do governo. V. PATRICK Devedjian : "Je souhaite que le Conseil constitutionnel soit à l'abri des soupçons”. Le Monde, 12 jan. 2010. Disponível em : http://www.lemonde.fr/politique/article/2010/01/12/mdevedjian-je-souhaite-que-le-conseil-constitutionnel-soit-a-l-abri-des-soupcons_1290457_823448.html. Acesso em: 16.mai.2011. Nos Estados Unidos, a decisão em Citizens United v. Federal Election Commission, invalidando os limites à participação financeira das empresas em campanhas eleitorais, foi duramente criticada pelo Presidente Barak Obama. V. New York Times, 24.jan.2010, p. A-20.

18 Sobre o fenômeno na América Latina, v. SIEDER, Rachel; SCHJOLDEN, Line; ANGELL, Alan. The judicialization of politics in Latin America. New York: Palgrave Macmillan, 2005.

${ }^{19}$ De acordo com YEPES, Rodrigo Uprimny. Judicialization of politics in Colombia. International Journal on Human Rights, 2007, v. 4, n. 6, p. 50: algumas das mais importantes hipóteses de judicialização da política na Colômbia envolveram: a) luta contra a corrupção e para mudança das práticas políticas; b) contenção do abuso das autoridades governamentais, especialmente em relação à declaração do estado de emergência ou estado de exceção; c) proteção das minoriais, assim como a autonomia individual; d) proteção das populações estigmatizadas ou aqueles em situação de fraqueza política; e e) interferência com políticas econômicas, em virtude da proteção judicial de direitos sociais.

${ }^{20}$ V. YEPES, Rodrigo Uprimny. Judicialization of politics in Colombia. International Journal on Human Rights, 2007, v. 4, n. 6, p. 57. V. tb. VIEIRA, José Ribas; CAMARGO, Margarida Maria Lacombe; SILVA, Alexandre Garrido. "O Supremo Tribunal Federal como arquiteto institucional: a judicialização da política e o ativismo judicial". In: Anais do I Forum de Grupos de Pesquisa em direito Constitucional e Teoria dos direitos. Rio de Janeiro: Faculdade Nacional de Direito, 2009, p. 44: "Em casos politicamente custosos, os poderes Legislativo e Executivo podem, de um modo estratégico, por meio de uma inércia deliberada, abrir um espaço para a atuação ativista dos tribunais. Temas profundamente controvertidos, sem perspectiva de consenso na sociedade, tais como a abertura dos arquivos da ditadura militar, uniões homoafetivas, aborto, entre outros, têm os seus custos políticos estrategicamente repassados para os tribunais, cujos integrantes não precisam passar pelo crivo do voto popular após suas decisões".
} 
Como consequência, quase todas as questões de relevância política, social ou moral foram discutidas ou já estão postas em sede judicial, especialmente perante o Supremo Tribunal Federal. A enunciação que se segue, meramente exemplificativa, serve como boa ilustração dos temas judicializados: (i) instituição de contribuição dos inativos na Reforma da Previdência (ADI 3105/DF); (ii) criação do Conselho Nacional de Justiça na Reforma do Judiciário (ADI 3367); (iii) pesquisas com células-tronco embrionárias (ADI 3510/DF); (iv) liberdade de expressão e racismo (HC 82424/RS - caso Ellwanger); (v) interrupção da gestação de fetos anencefálicos (ADPF 54/DF); (vi) restrição ao uso de algemas (HC 91952/SP e Súmula Vinculante no 11); (vii) demarcação da reserva indígena Raposa Serra do Sol (Pet 3388/RR); (viii) legitimidade de ações afirmativas e quotas sociais e raciais (ADI 3330); (ix) vedação ao nepotismo (ADC 12/DF e Súmula $n^{\circ} 13$ ); (x) não-recepção da Lei de Imprensa (ADPF 130/DF). A lista poderia prosseguir indefinidamente, com a identificação de casos de grande visibilidade e repercussão, como a extradição do militante italiano Cesare Battisti (Ext 1085/Itália e MS 27875/DF), a questão da importação de pneus usados (ADPF 101/DF) ou da proibição do uso do amianto (ADI 3937/SP). Merece destaque a realização de diversas audiências públicas, perante o STF, para debater a questão da judicialização de prestações de saúde, notadamente o fornecimento de medicamentos e de tratamentos fora das listas e dos protocolos do Sistema Único de Saúde (SUS) ${ }^{21}$.

Uma observação final relevante dentro deste tópico. No Brasil, como assinalado, a judicialização decorre, sobretudo, de dois fatores: o modelo de constitucionalização abrangente e analítica adotado; e o sistema de controle de constitucionalidade vigente entre nós, que combina a matriz americana - em que todo juiz e tribunal pode pronunciar a invalidade de uma norma no caso concreto - e a matriz européia, que admite ações diretas ajuizáveis perante a corte constitucional. Nesse segundo caso, a validade constitucional de leis e atos normativos é discutida em tese, perante o Supremo Tribunal Federal, fora de uma situação concreta de litígio. Essa fórmula foi maximizada no sistema brasileiro pela admissão de uma variedade de ações diretas e pela previsão constitucional de amplo direito de propositura. Nesse contexto, a judicialização constitui um fato inelutável, uma circunstância decorrente do desenho institucional vigente, e não uma opção política do Judiciário. Juízes e tribunais, uma vez provocados pela via processual adequada, não têm a alternativa de se

\footnotetext{
21 Disponível em: http://www.stf.jus.br/portal/cms/verTexto.asp?servico=processoAudienciaPublica Saude.
} Acesso em: 16.mai.2011. 
pronunciarem ou não sobre a questão. Todavia, o modo como venham a exercer essa competência é que vai determinar a existência ou não de ativismo judicial.

\section{O ATIVISMO JUDICIAL}

Ativismo judicial é uma expressão cunhada nos Estados Unidos ${ }^{22}$ e que foi empregada, sobretudo, como rótulo para qualificar a atuação da Suprema Corte durante os anos em que foi presidida por Earl Warren, entre 1954 e $1969^{23}$. Ao longo desse período, ocorreu uma revolução profunda e silenciosa em relação a inúmeras práticas políticas nos Estados Unidos, conduzida por uma jurisprudência progressista em matéria de direitos fundamentais ${ }^{24}$. Todas essas transformações foram efetivadas sem qualquer ato do Congresso ou decreto presidencial $^{25}$. A partir daí, por força de uma intensa reação conservadora, a expressão ativismo judicial assumiu, nos Estados Unidos, uma conotação negativa, depreciativa,

\footnotetext{
${ }^{22}$ A locução "ativismo judicial" foi utilizada, pela primeira vez, em artigo de um historiador sobre a Suprema Corte americana no período do New Deal, publicado em revista de circulação ampla. V. SCHLESINGER, Arthur M., Jr., The Supreme Court: 1947. Fortune, jan. 1947, v. 35, p. 208 apud KMIEC, Keenan D. The origin and current meanings of 'judicial activism'. California Law Review, out.2004, n. 92, p. 1446. A descrição feita por Schlesinger da divisão existente na Suprema Corte, à época, é digna de transcrição, por sua atualidade no debate contemporâneo: "Esse conflito pode ser descrito de diferentes maneiras. O grupo de Black e de Douglas acredita que a Suprema Corte pode desempenhar um papel afirmativo na promoção do bem-estar social; o grupo de Frankfurter e Jackson defende uma postura de auto-contenção judicial. Um grupo está mais preocupado com a utilização do poder judicial em favor de sua própria concepção do bem social; o outro, com a expansão da esfera de atuação do Legislativo, mesmo que isso signifique a defesa de pontos de vista que eles pessoalmente condenam. Um grupo vê a Corte como instrumento para a obtenção de resultados socialmente desejáveis; o segundo, como um instrumento para permitir que os outros Poderes realizem a vontade popular, seja ela melhor ou pior. Em suma, Black-Douglas e seus seguidores parecem estar mais voltados para a solução de casos particulares de acordo com suas próprias concepções sociais; Frankfurter-Jackson e seus seguidores, com a preservação do Judiciário na sua posição relevante, mas limitada, dentro do sistema americano".
}

${ }^{23}$ Sobre o tema, em língua portuguesa, v. BARROSO, Luís Roberto. "A americanização do direito constitucional e seus paradoxos". In: Temas de direito constitucional, t. IV. Rio de Janeiro: Renovar, 2009, p. 144 e s. (O legado de Warren: ativismo judicial e proteção dos direitos fundamentais). Para uma interessante biografia de Warren, bem como um denso relato do período, v. NEWTON, Jim. Justice for all: Earl Warren and the Nation he made. New York: Riverhead, 2006.

${ }^{24}$ Alguns exemplos representativos: considerou-se ilegítima a segregação racial nas escolas (Brown v. Board of Education, 1954); foram assegurados aos acusados em processo criminal o direito de defesa por advogado (Gideon v. Wainwright, 1963) e o direito à não-auto-incriminação (Miranda v. Arizona, 1966); e de privacidade, sendo vedado ao Poder Público a invasão do quarto de um casal para reprimir o uso de contraceptivos (Griswold v. Connecticut, 1965). Houve decisões marcantes, igualmente, no tocante à liberdade de imprensa (New York Times v. Sullivan, 1964) e a direitos políticos (Baker v. Carr, 1962). Em 1973, já sob a presidência de Warren Burger, a Suprema Corte reconheceu direitos de igualdade às mulheres (Richardson v. Frontiero, 1973), assim como em favor dos seus direitos reprodutivos, vedando a criminalização do aborto até o terceiro mês de gestação (Roe v. Wade).

${ }^{25}$ NEWTON, Jim. Justice for all: Earl Warren and the Nation he made. New York: Riverhead, 2006.p. 405. 
equiparada ao exercício impróprio do poder judicial ${ }^{26}$. Todavia, depurada dessa crítica ideológica - até porque pode ser progressista ou conservadora ${ }^{27}$ - a ideia de ativismo judicial está associada a uma participação mais ampla e intensa do Judiciário na concretização dos valores e fins constitucionais, com maior interferência no espaço de atuação dos outros dois Poderes. Em muitas situações, sequer há confronto, mas mera ocupação de espaços vazios.

No Brasil, há diversos precedentes de postura ativista do STF, manifestada por diferentes linhas de decisão. Dentre elas se incluem: a) a aplicação direta da Constituição a situações não expressamente contempladas em seu texto e independentemente de manifestação do legislador ordinário, como se passou em casos como o da imposição de fidelidade partidária e o da vedação do nepotismo; b) a declaração de inconstitucionalidade de atos normativos emanados do legislador, com base em critérios menos rígidos que os de patente e ostensiva violação da Constituição, de que são exemplos as decisões referentes à verticalização das coligações partidárias e à cláusula de barreira; c) a imposição de condutas ou de abstenções ao Poder Público, tanto em caso de inércia do legislador - como no precedente sobre greve no serviço público ou sobre criação de município - como no de políticas públicas insuficientes, de que têm sido exemplo as decisões sobre direito à saúde. Todas essas hipóteses distanciam juízes e tribunais de sua função típica de aplicação do direito vigente e os aproximam de uma função que mais se assemelha à de criação do próprio direito.

\footnotetext{
${ }^{26}$ V. BARNETT, Randy E.. Constitututional clichês. Capital University Law Review, Columbus, 2007, n. 36, p. 495: "Normalmente, no entanto, 'ativismo judicial' é empregado para criticar uma prática judicial que deve ser evitada pelos juízes e que merece a oposição do público". Keenan D. Kmiec, The origin and current meanings of 'judicial activism', California Law Review 92:1441, 2004, p. 1463 e s. afirma que não se trata de um conceito monolítico e aponta cinco sentidos em que o termo tem sido empregado no debate americano, no geral com uma conotação negativa: a) declaração de inconstitucionalidade de atos de outros Poderes que não sejam claramente inconstitucionais; b) ignorar precedentes aplicáveis; c) legislação pelo Judiciário; d) distanciamento das metodologias de interpretação normalmente aplicadas e aceitas; e e) julgamentos em função dos resultados.

27 Como assinalado no texto, a expressão ativismo judicial foi amplamente utilizada para estigmatizar a jurisprudência progressista da Corte Warren. É bem de ver, no entanto, que o ativismo judicial precedeu a criação do termo e, nas suas origens, era essencialmente conservador. De fato, foi na atuação proativa da Suprema Corte que os setores mais reacionários encontraram amparo para a segregação racial (Dred Scott $v$. Sanford, 1857) e para a invalidação das leis sociais em geral (Era Lochner, 1905-1937), culminando no confronto entre o Presidente Roosevelt e a Corte, com a mudança da orientação jurisprudencial contrária ao intervencionismo estatal (West Coast v. Parrish, 1937). A situação se inverteu no período que foi de meados da década de 50 a meados da década de 70 do século passado. Todavia, depois da guinada conservadora da Suprema Corte, notadamente no período da presidência de William Rehnquist (1986-2005), coube aos progressistas a crítica severa ao ativismo judicial que passou a desempenhar. V. CROSS, Frank B.; LINDQUIST, Stefanie A. The scientific study of judicial activism. Minnesota Law Review, 2006-2007, n. 91, p. 1753 e 1757-8; SUNSTEIN, Cass. Tilting the scales rightward. New York Times, 26 abr. 2001 ("um notável período de ativismo judicial direitista") e Erwin Chemerinsky, Perspective on Justice: and federal law got narrower, narrower, Los Angeles Times, 18 mai. 2000 (“ativismo judicial agressivo e conservador”).
} 
A judicialização, como demonstrado acima, é um fato, uma circunstância do desenho institucional brasileiro. Já o ativismo é uma atitude, a escolha de um modo específico e proativo de interpretar a Constituição, expandindo o seu sentido e alcance. Normalmente, ele se instala - e este é o caso do Brasil - em situações de retração do Poder Legislativo, de um certo descolamento entre a classe política e a sociedade civil, impedindo que determinadas demandas sociais sejam atendidas de maneira efetiva. $\mathrm{O}$ oposto do ativismo é a autocontenção judicial, conduta pela qual o Judiciário procura reduzir sua interferência nas ações dos outros Poderes ${ }^{28}$. A principal diferença metodológica entre as duas posições está em que, em princípio, o ativismo judicial legitimamente exercido procura extrair o máximo das potencialidades do texto constitucional, inclusive e especialmente construindo regras específicas de conduta a partir de enunciados vagos (princípios, conceitos jurídicos indeterminados). Por sua vez, a autocontenção se caracteriza justamente por abrir mais espaço à atuação dos Poderes políticos, tendo por nota fundamental a forte deferência em relação às ações e omissões desses últimos.

\section{CRÍTICAS À EXPANSÃO DA INTERVENÇÃO JUDICIAL NA VIDA BRASILEIRA}

Diversas objeções têm sido opostas, ao longo do tempo, à expansão do Poder Judiciário nos Estados constitucionais contemporâneos. Identificam-se aqui três delas. Tais críticas não infirmam a importância do papel desempenhado por juízes e tribunais nas democracias modernas, mas merecem consideração séria. O modo de investidura dos juízes e membros de tribunais, sua formação específica e o tipo de discurso que utilizam são aspectos que exigem reflexão. Ninguém deseja o Judiciário como instância hegemônica e a interpretação constitucional não pode se transformar em usurpação da função legislativa. Aqui, como em quase tudo mais, impõem-se as virtudes da prudência e da moderação ${ }^{29}$.

\section{Crítica político-ideológica}

\footnotetext{
${ }^{28}$ Por essa linha, juízes e tribunais (i) evitam aplicar diretamente a Constituição a situações que não estejam no seu âmbito de incidência expressa, aguardando o pronunciamento do legislador ordinário; (ii) utilizam critérios rígidos e conservadores para a declaração de inconstitucionalidade de leis e atos normativos; e (iii) abstêm-se de interferir na definição das políticas públicas.

${ }^{29}$ V. ARISTÓTELES. Ética a Nicômaco. 2. ed. São Paulo: Edipro, 2007, p. 70 e 77: "Em primeiro lugar, temos que observar que as qualidades morais são de tal modo constituídas que são destruídas pelo excesso e pela deficiência. (...) [O] excesso e a deficiência são uma marca do vício e a observância da mediania uma marca da virtude...".
} 
Juízes e membros dos tribunais não são agentes públicos eleitos. Sua investidura não tem o batismo da vontade popular. Nada obstante isso, quando invalida atos do Legislativo ou do Executivo ou impõe-lhes deveres de atuação, o Judiciário desempenha um papel que é inequivocamente político. Essa possibilidade de as instâncias judiciais sobreporem suas decisões às dos agentes políticos eleitos gera aquilo que em teoria constitucional foi denominado de dificuldade contramajoritária ${ }^{30}$. A jurisdição constitucional e a atuação expansiva do Judiciário têm recebido, historicamente, críticas de natureza política, que questionam sua legitimidade democrática e sua suposta maior eficiência na proteção dos direitos fundamentais ${ }^{31}$. Ao lado dessas, há, igualmente, críticas de cunho ideológico, que veem no Judiciário uma instância tradicionalmente conservadora das distribuições de poder e de riqueza na sociedade. Nessa perspectiva, a judicialização funcionaria como uma reação das elites tradicionais contra a democratização, um antídoto contra a participação popular e a política majoritária ${ }^{32}$.

\section{Crítica quanto à capacidade institucional}

Cabe aos três Poderes interpretar a Constituição e pautar sua atuação com base nela. Mas, em caso de divergência, a palavra final é do Judiciário. Essa primazia não significa, porém, que toda e qualquer matéria deva ser decidida em um tribunal. Para evitar que o

\footnotetext{
${ }^{30}$ BICKEL, Alexander. The least dangerous branch. New Haven: Yale University Press, 1986, p. 16-23: “A questão mais profunda é que o controle de constitucionalidade (judicial review) é uma força contramajoritária em nosso sistema. (...) [Q]uando a Suprema Corte declara inconstitucional um ato legislativo ou um ato de um membro eleito do Executivo, ela se opõe à vontade de representantes do povo, o povo que está aqui e agora; ela exerce um controle, não em nome da maioria dominante, mas contra ela. (...) O controle de constitucionalidade, no entanto, é o poder de aplicar e interpretar a Constituição, em matérias de grande relevância, contra a vontade da maioria legislativa, que, por sua vez, é impotente para se opor à decisão judicial”.

${ }^{31}$ Um dos principais representantes dessa corrente é Jeremy Waldron, autor de Law and disagreement, 1999, e The core of the case against judicial review, Yale Law Journal. New Haven, 2006, v. 115, n. 6. Sua tese central é a de que nas sociedades democráticas nas quais o Legislativo não seja "disfuncional", as divergências acerca dos direitos devem ser resolvidas no âmbito do processo legislativo e não do processo judicial.

${ }^{32}$ V. HIRSCHL, Ran. Towards juristocracy: the origins and consequences of the new constitutionalism. Cambridge: Harvard University, 2004. Após analisar as experiências de Canadá, Nova Zelândia, Israel e África do Sul, o autor conclui que o aumento do poder judicial por via da constitucionalização é, no geral, "um pacto estratégico entre três partes: as elites políticas hegemônicas (e crescentemente ameaçadas) que pretendem proteger suas preferências políticas contra as vicissitudes da política democrática; as elites econômicas que comungam da crença no livre mercado e da antipatia em relação ao governo; e cortes supremas que buscar fortalecer seu poder simbólico e sua posição institucional” (p. 214). Nos Estados Unidos, em linha análoga, uma corrente de pensamento referida como "constitucionalismo popular" também critica a ideia de supremacia judicial. V., dentre muitos, TUSHNET, Mark. Taking the constitution away from the courts. Princeton: Princeton University Press, 1999, p. 177, onde escreveu: "Os liberais (progressistas) de hoje parecem ter um profundo medo do processo eleitoral. Cultivam um entusiasmo no controle judicial que não se justifica, diante das experiências recentes. Tudo porque têm medo do que o povo pode fazer".
} 
Judiciário se transforme em uma indesejável instância hegemônica ${ }^{33}$, a doutrina constitucional tem explorado duas ideias destinadas a limitar a ingerência judicial: a de capacidade institucional e a de efeitos sistêmicos ${ }^{34}$. Capacidade institucional envolve a determinação de qual Poder está mais habilitado a produzir a melhor decisão em determinada matéria. Temas envolvendo aspectos técnicos ou científicos de grande complexidade podem não ter no juiz de direito o árbitro mais qualificado, por falta de informação ou de conhecimento específico ${ }^{35}$. Também o risco de efeitos sistêmicos imprevisíveis e indesejáveis podem recomendar uma posição de cautela e de deferência por parte do Judiciário. O juiz, por vocação e treinamento, normalmente estará preparado para realizar a justiça do caso concreto, a microjustiça ${ }^{36}$, sem condições, muitas vezes, de avaliar o impacto de suas decisões sobre um segmento econômico ou sobre a prestação de um serviço público ${ }^{37}$.

\section{Crítica quanto à limitação do debate}

$\mathrm{O}$ mundo do direito tem categorias, discurso e métodos próprios de argumentação. $\mathrm{O}$ domínio desse instrumental exige conhecimento técnico e treinamento específico, não acessíveis à generalidade das pessoas. A primeira consequência drástica da judicialização é a

\footnotetext{
33 A expressão é do Ministro Celso de Mello. V. STF, DJ, 12 mai.2000, MS 23.452/RJ, Rel. Min. Celso de Mello.

${ }^{34}$ V. SUNSTEIN, Cass; VERMEULLE, Adrian. Intepretation and institutions, Public Law and Legal Theory Working Paper No. 28. University of Chicago Law School, 2002: “Ao chamarmos atenção para as capacidades institucionais e para os efeitos sistêmicos, estamos sugerindo a necessidade de um tipo de virada institucional no estudo das questões de interpretação jurídicas" (p. 2). Sobre o tema, v. tb. VERMEULE, Adrian. Foreword: system effects and the constitution. Harvard Law Review, Cambridge, nov. 2009, n. 123, p. 4.

${ }^{35}$ Por exemplo: em questões como demarcação de terras indígenas ou transposição de rios, em que tenha havido estudos técnicos e científicos adequados, a questão da capacidade institucional deve ser sopesada de maneira
} criteriosa.

${ }^{36}$ BARCELLOS, Ana Paula de. Constitucionalização das políticas públicas em matéria de direitos fundamentais: o controle político-social e o controle jurídico no espaço democrático. Revista de direito do Estado, Rio de Janeiro jul./set.2006, v. 1, n. 3, p. 34. Também sobre o tema, v. SARMENTO, Daniel. "Interpretação constitucional, pré-compreensão e capacidades institucionais do intérprete". In: SOUZA NETO, Cláudio Pereira de; SARMENTO, Daniel; BINENBOJM, Gustavo (coords.), Vinte anos da Constituição Federal de 1988. Rio de Janeiro: Ed. Lúmen Júris, 2008, p. 317: “[U]ma teoria hermenêutica construída a partir de uma imagem romântica do juiz pode produzir resultados desastrosos quando manejada por magistrados de carne e osso que não correspondam àquela idealização...”.

37 Exemplo emblemático nessa matéria tem sido o setor de saúde. Ao lado de intervenções necessárias e meritórias, tem havido uma profusão de decisões extravagantes ou emocionais em matéria de medicamentos e terapias, que põem em risco a própria continuidade das políticas públicas de saúde, desorganizando a atividade administrativa e comprometendo a alocação dos escassos recursos públicos. Sobre o tema, v. BARROSO, Luís Roberto. "Da falta de efetividade à constitucionalização excessiva: direito à saúde, fornecimento gratuito de medicamentos e parâmetros para a atuação judicial”. In: Temas de direito constitucional, tomo IV. Rio de Janeiro: Renovar, 2009. 
elitização do debate e a exclusão dos que não dominam a linguagem nem têm acesso aos locus de discussão jurídica ${ }^{38}$. Institutos como audiências públicas, amicus curiae e direito de propositura de ações diretas por entidades da sociedade civil atenuam mas não eliminam esse problema. Surge, assim, o perigo de se produzir uma apatia nas forças sociais, que passariam a ficar à espera de juízes providenciais ${ }^{39}$. Na outra face da moeda, a transferência do debate público para o Judiciário traz uma dose excessiva de politização dos tribunais, dando lugar a paixões em um ambiente que deve ser presidido pela razão ${ }^{40}$. No movimento seguinte, processos passam a tramitar nas manchetes de jornais - e não na imprensa oficial - e juízes trocam a racionalidade plácida da argumentação jurídica por embates próprios da discussão parlamentar, movida por visões políticas contrapostas e concorrentes ${ }^{41}$.

\section{IMPORTÂNCIA E LIMITES DA JURISDIÇÃO CONSTITUCIONAL NAS DEMOCRACIAS} CONTEMPORÂNEAS

A jurisdição constitucional pode não ser um componente indispensável do constitucionalismo democrático, mas tem servido bem à causa, de uma maneira geral ${ }^{42}$. Ela é um espaço de legitimação discursiva ou argumentativa das decisões políticas que coexiste

\footnotetext{
${ }^{38}$ V. WALDRON, Jeremy, The core case against judicial review. The Yale Law Journal. New Haven, 2006 , v. 115, n. 6, p. 1353: “A judicialização tende a mudar o foco da discussão pública, que passa de um ambiente onde as razões podem ser postas de maneira aberta e abrangente para um outro altamente técnico e formal, tendo por objeto textos e idéias acerca de interpretação" (tradução livre e ligeiramente editada).

39 YEPES, Rodrigo Uprimny. Judicialization of politics in Colombia. International Journal on Human Rights, 2007, v. 4, n. 6, p. 63: "O uso de argumentos jurídicos para resolver problemas sociais complexos pode dar a impressão de que a solução para muitos problemas políticos não exige engajamento democrático, mas em vez disso juízes e agentes públicos providenciais".

${ }^{40}$ Exemplo emblemático de debate apaixonado foi o que envolveu o processo de extradição do ex-militante da esquerda italiana Cesare Battisti. Na ocasião, assinalou o Ministro Eros Grau: "Parece que não há condições no tribunal de um ouvir o outro, dada a paixão que tem presidido o julgamento deste caso". Sobre o ponto, v. RECONDO, Felipe; GALlUCI, Mariângela. "Caso Battisti expõe crise no STF”. In: Estado de São Paulo, São Paulo, 22.11.2009.

${ }^{41}$ Em 22 abr.2009, diferentes visões sobre a relação Judiciário, mídia e sociedade levaram a uma ríspida discussão entre os Ministros Gilmar Mendes e Joaquim Barbosa. Disponível em: http://oglobo.globo.com/pais/noblat/posts/2009/04/22/na-integra-bate-boca-entre-joaquim-barbosa-mendes179585.asp. Acesso em: 16.mai.2011.

${ }^{42}$ V. GRIMM, Dieter. Jurisdição constitucional e democracia. Revista de Direito do Estado, Rio de Janeiro, 2006, v.1, n. 4, p. 9: “A jurisdição constitucional não é nem incompatível nem indispensável à democracia. (...) [Há] suficientes provas históricas de que um estado democrático pode dispensar o controle de constitucionalidade. (...) Ninguém duvidaria do caráter democrático de Estados como o Reino Unido e a Holanda, que não adotam o controle de constitucionalidade". Sobre o tema, inclusive com uma reflexão acerca da posição de Dieter Grimm aplicada ao Brasil, v. PIRES, Thiago Magalhães. Crônicas do subdesenvolvimento: jurisdição constitucional e democracia no Brasil, Revista de direito do Estado, Rio de Janeiro, out./dez.2008, v.3, n.12, p. 194 e s.
} 
com a legitimação majoritária, servindo-lhe de "contraponto e complemento" "43. Isso se torna especialmente verdadeiro em países de redemocratização mais recente, como o Brasil, onde o amadurecimento institucional ainda se encontra em curso, enfrentando uma tradição de hegemonia do Executivo e uma persistente fragilidade do sistema representativo ${ }^{44}$. As constituições contemporâneas, como já se assinalou, desempenham dois grandes papéis: (i) o de condensar os valores políticos nucleares da sociedade, os consensos mínimos quanto a suas instituições e quanto aos direitos fundamentais nela consagrados; e (ii) o de disciplinar o processo político democrático, propiciando o governo da maioria, a participação da minoria e a alternância no poder ${ }^{45}$. Pois este é o grande papel de um tribunal constitucional, do Supremo Tribunal Federal, no caso brasileiro: proteger e promover os direitos fundamentais, bem como resguardar as regras do jogo democrático. Eventual atuação contramajoritária do Judiciário em defesa dos elementos essenciais da Constituição se dará a favor e não contra a democracia $^{46}$.

Nas demais situações - isto é, quando não estejam em jogo os direitos fundamentais ou os procedimentos democráticos -, juízes e tribunais devem acatar as escolhas legítimas feitas pelo legislador, assim como ser deferentes com o exercício razoável de discricionariedade pelo administrador, abstendo-se de sobrepor-lhes sua própria valoração política $^{47}$. Isso deve ser feito não só por razões ligadas à legitimidade democrática, como também em atenção às capacidades institucionais dos órgãos judiciários e sua impossibilidade

\footnotetext{
${ }^{43}$ MENDONÇA, Eduardo Bastos de. A constitucionalização da política: entre o inevitável e o excessivo, p. 10. Artigo inédito, gentilmente cedido pelo autor.

${ }^{44} \mathrm{Um}$ dos principais críticos da judicial review, isto é, à possibilidade de cortes de justiça declararem a inconstitucionalidade de atos normativos, Jeremy Waldron, no entanto, reconhece que ela pode ser necessária para enfrentar patologias específicas, em um ambiente em que certas características políticas e institucionais das democracias liberais não estejam totalmente presentes. V. WALDRON, Jeremy, The core case against judicial review. The Yale Law Journal, New Haven, 2006, v. 115, n. 6, p. 1359 e s.
}

45 BARROSO, Luís Roberto. Curso de direito constitucional contemporâneo. 1. ed. Rio de Janeiro: Saraiva, 2009, p. 89-90.

${ }^{46}$ Para uma crítica da visão do Judiciário como instância de proteção das minorias e de defesa das regras democráticas, v. ROS, Luciano da. Tribunais como árbitros ou como instrumentos de oposição: uma tipologia a partir dos estudos recentes sobre judicialização da política com aplicação ao caso brasileiro contemporâneo, Direito, Estado e Sociedade, jul./dez. 2007, n. 31, p. 100-1, onde averbou: "Pode-se afirmar que tribunais são instituições que operam rigorosamente dentro dos limites que a dinâmica das outras forças políticas e institucionais lhes impõem, raramente decidindo fora do círculo de preferências dos atores políticos. A idéia de que tribunais salvaguardam a democracia e a Constituição contra tudo e contra todos, como muitas vezes se veicula nos círculos acadêmicos, pode ser considerada ingênua”.

$47 \mathrm{Na}$ jurisprudência norte-americana, o caso Chevron é o grande precedente da teoria da deferência administrativa em relação à interpretação razoável dada pela Administração. De fato, em Chevron USA Inc. vs. National Resources Defense Council Inc. (467 U.S. 837 (1984) ficou estabelecido que, havendo ambiguidade ou delegação legislativa para a agência, o Judiciário somente deve intervir se a Administração (no caso, uma agência reguladora) tiver atuado contra legem ou de maneira irrazoável. 
de prever e administrar os efeitos sistêmicos das decisões proferidas em casos individuais. Os membros do Judiciário não devem presumir demais de si próprios - como ninguém deve, aliás, nessa vida -, supondo-se experts em todas as matérias. Por fim, o fato de a última palavra acerca da interpretação da Constituição ser do Judiciário não o transforma no único nem no principal - foro de debate e de reconhecimento da vontade constitucional a cada tempo. A jurisdição constitucional não deve suprimir nem oprimir a voz das ruas, o movimento social, os canais de expressão da sociedade. Nunca é demais lembrar que o poder emana do povo, não dos juízes.

\section{Parte II}

\section{DIREITO E POLÍTICA: A CONCEPÇÃO TRADICIONAL}

\section{NOTAS SOBRE A DISTINÇÃO ENTRE DIREITO E POLÍTICA}

A separação entre direito e política tem sido considerada como essencial no Estado constitucional democrático. $\mathrm{Na}$ política, vigoram a soberania popular e o princípio majoritário. O domínio da vontade. No direito, vigora o primado da lei (the rule of law) e do respeito aos direitos fundamentais. O domínio da razão. A crença mitológica nessa distinção tem resistido ao tempo e às evidências. Ainda hoje, já avançado o século XXI, mantém-se a divisão tradicional entre o espaço da política e o espaço do direito ${ }^{48}$. No plano de sua criação, não há como o direito ser separado da política, na medida em que é produto do processo constituinte ou do processo legislativo, isto é, da vontade das maiorias. O direito é, na verdade, um dos principais produtos da política, o troféu pelo qual muitas batalhas são disputadas $^{49}$. Em um Estado de direito, a Constituição e as leis, a um só tempo, legitimam e limitam o poder político.

Já no plano da aplicação do direito, sua separação da política é tida como possível e desejável. Tal pretensão se realiza, sobretudo, por mecanismos destinados a evitar a ingerência do poder político sobre a atuação judicial. Isso inclui limitações ao próprio legislador, que não pode editar leis retroativas, destinadas a atingir situações $\operatorname{concretas}^{50}$. Essa

\footnotetext{
48 V. KRAMER, Larry. The people themselves: popular constitutionalism and judicial review. New York: Oxford University Press, 2004, p. 7.

${ }^{49}$ V. WHITTINGTON, Keith E.; KELEMEN, R. Daniel; CALDEIRA, Gregory A. (eds.), The Oxford handbook of law and politics. Oxford: Oxford University Press, 2008, p. 3.

${ }^{50}$ GRIMM, Dieter. Constituição e política. Belo Horizonte: Del Rey, 2006, p. 13.
} 
separação é potencializada por uma visão tradicional e formalista do fenômeno jurídico. Nela se cultivam crenças como a da neutralidade científica, da completude do direito e a da interpretação judicial como um processo puramente mecânico de concretização das normas jurídicas, em valorações estritamente técnicas ${ }^{51}$. Tal perspectiva esteve sob fogo cerrado ao longo de boa parte do século passado, tendo sido criticada por tratar questões políticas como se fossem linguísticas e por ocultar escolhas entre diferentes possibilidades interpretativas por trás do discurso da única solução possível ${ }^{52}$. Mais recentemente, autores diversos têm procurado resgatar o formalismo jurídico, em uma versão requalificada, cuja ênfase é a valorização das regras e a contenção da discricionariedade judicial ${ }^{53}$.

\section{CONSTITUIÇÃO E PODERES CONSTITUÍDOS}

A Constituição é o primeiro e principal elemento na interface entre política e direito. Cabe a ela transformar o poder constituinte originário - energia política em estado quase puro, emanada da soberania popular - em poder constituído, que são as instituições do Estado, sujeitas à legalidade jurídica, à rule of law. É a Constituição que institui os Poderes do Estado, distribuindo-lhes competências diversas ${ }^{54}$. Dois deles recebem atribuições essencialmente políticas: o Legislativo e o Executivo. Ao Legislativo toca, precipuamente, a criação do

\footnotetext{
${ }^{51} \mathrm{O}$ termo formalismo é empregado aqui para identificar posições que exerceram grande influência em todo o mundo, como a da Escola da Exegese, na França, a Jurisprudência dos Conceitos, na Alemanha, e o Formalismo Jurídico, nos Estados Unidos, cuja marca essencial era a da concepção mecanicista do direito, com ênfase na lógica formal e grande desconfiança em relação à interpretação judicial.

${ }^{52}$ Para TAMANAHA, Brian Z.. Beyond the formalist-realist divide: the role of politics in judging. Princeton: Princeton University Press, 2010, a existência do formalismo jurídico, com as características que lhe são atribuídas, não corresponde à realidade histórica. Segundo ele, ao menos nos Estados Unidos, essa foi uma invenção de alguns realistas jurídicos, que se apresentaram para combater uma concepção que jamais exisitiu, ao menos não com tais características: autonomia e completude do direito, soluções únicas e interpretação mecânica. A tese refoge ao conhecimento convencional e certamente suscitará polêmica.
}

53 V. SCHAUER, Frederick. "Formalism: legal, constitutional, judicial”. In: WHITTINGTON, Keith E.; KELEMEN, R. Daniel; CALDEIRA, Gregory A. (eds.), The Oxford handbook of law and politics. Oxford: Oxford University Press, 2008, p. 428-36; e STRUCHINER, Noel. "Posturas interpretativas e modelagem institucional: a dignidade (contingente) do formalismo jurídico". In: SARMENTO, Daniel (coord.). Filosofia e teoria constitucional contemporânea. Rio de Janeiro: Lumen Juris, 2009, p. 463-82. Sobre as ambiguidades do termo formalismo, v. STONE, Martin. "Verbete 'formalismo"”. In: COLEMAN, Jules; SHAPIRO, Scott (Eds). The Oxford handbook of jurisprudence and philosophy of Law. Oxford: Oxford University Press, 2002, p. 166205.

${ }^{54} \mathrm{O}$ poder constituinte, titularizado pelo povo, elabora a Constituição. A Constituição tem por propósito submeter a política ao direito, impondo a ela regras procedimentais e determinados valores substantivos. Isso não significa, todavia, quer a judicialização plena quer a supressão da política, mas a mera existência de limites, de uma "moldura", como referido por Dieter Grimm, que acrescentou: "[U]ma política totalmente judicializada estaria no fundo despida de seu caráter político e por fim reduzida à administração" (Constituição e política, 2006, p. 10). 
direito positivo ${ }^{55}$. Já o Executivo, no sistema presidencialista brasileiro, concentra as funções de chefe de Estado e de chefe de governo, conduzindo com razoável proeminência a política interna e externa. Legislativo e Executivo são o espaço por excelência do processo político majoritário, feito de campanhas eleitorais, debate público e escolhas discricionárias. Um universo no qual o título principal de acesso é o voto: o que elege, reelege ou deixa de fora.

Já ao Poder Judiciário são reservadas atribuições tidas como fundamentalmente técnicas. Ao contrário do chefe do Executivo e dos parlamentares, seus membros não são eleitos. Como regra geral, juízes ingressam na carreira no primeiro grau de jurisdição, mediante concurso público. O acesso aos tribunais de segundo grau se dá por via de promoção, conduzida pelo órgão de cúpula do próprio tribunal ${ }^{56}$. No tocante aos tribunais superiores, a investidura de seus membros sofre maior influência política, mas, ainda assim, está sujeita a parâmetros constitucionais ${ }^{57}$. A atribuição típica do Poder Judiciário consiste na aplicação do direito a situações em que tenha surgido uma disputa, um litígio entre partes. Ao decidir a controvérsia - esse o entendimento tradicional -, o juiz faz prevalecer, no caso concreto, a solução abstratamente prevista na lei. Desempenharia, assim, uma função técnica de conhecimento, de mera declaração de um resultado já previsto, e não uma atividade criativa, suscetível de influência política ${ }^{58}$. Mesmo nos casos de controle de constitucionalidade em tese - isto é, de discussão acerca da validade abstrata de uma lei -, o Judiciário estaria fazendo prevalecer a vontade superior da Constituição sobre a decisão política majoritária do Legislativo.

\section{A PRETENSÃO DE AUTONOMIA DO JUDICIÁRIO E DO DIREITO EM RELAÇÃO À POLÍTICA}

\footnotetext{
${ }^{55}$ Note-se que no âmbito da atuação política do Legislativo inclui-se, com destaque, a fiscalização do governo e da administração pública. Importante ressaltar, igualmente, que nos países presidencialistas - e no Brasil, especialmente -, o chefe do Executivo tem participação destacada no processo legislativo, seja pela iniciativa seja pelo poder de sanção ou veto. Sobre o tema, v. CLÈVE, Clèmerson Merlin. A atividade legislativa do Poder Executivo. 2.ed. São Paulo: Revista dos Tribunais, 2000, p. 99-118.

56 Salvo no tocante ao chamado quinto constitucional, em que há participação do chefe do Executivo na designação de advogados e membros do Ministério Público para o tribunal (CF, art. 94).

${ }^{57}$ Nos tribunais superiores - Superior Tribunal de Justiça, Tribunal Superior Eleitoral, Tribunal Superior do Trabalho e Superior Tribunal Militar -, a indicação de seus ministros é feita pelo Presidente da República, com aprovação do Senado Federal (exceto no caso do TSE). Ainda assim, existem balizamentos constitucionais, que incluem, conforme o caso, exigências de notório saber jurídico e reputação ilibada, idade e origem funcional. $V$. CF, arts. 101, 104, 119, 111-A e 123.

${ }^{58}$ Sobre a interpretação jurídica como mera função técnica de conhecimento, v. TROPER, Michel, verbete "Interprétation”. In: ALLAND, Denis; RIALS, Stéphan. Dictionnaire de la culture juridique. Paris: Quadrige / LAMY-PUF, 2003, p. 843.
} 
A maior parte dos Estados democráticos do mundo reserva uma parcela de poder político para ser exercido pelo Judiciário, isto é, por agentes públicos que não são eleitos. Quando os órgãos judiciais resolvem disputas entre particulares, determinando, por exemplo, o pagamento de uma indenização por quem causou um acidente, decretando um divórcio ou o despejo de um imóvel, não há muita polêmica sobre a legitimidade do poder que exerce. A Constituição confere a ele competência para solucionar os litígios em geral e é disso que se trata. A questão ganha em complexidade, todavia, quando o Judiciário atua em disputas que envolvem a validade de atos estatais ou nas quais o Estado - isto é, outros órgãos de Poder seja parte. É o que ocorre quando declara inconstitucional a cobrança de um tributo, suspende a execução de uma obra pública por questões ambientais ou determina a um hospital público que realize tratamento experimental em paciente que solicitou tal providência em juízo. Nesses casos, juízes e tribunais sobrepõem sua vontade à de agentes públicos de outros Poderes, eleitos ou nomeados para o fim específico de fazerem leis, construírem estradas ou definirem as políticas de saúde.

Para blindar a atuação judicial da influência imprópria da política, a cultura jurídica tradicional sempre se utilizou de dois grandes instrumentos: a independência do Judiciário em relação aos órgãos propriamente políticos de governo; e a vinculação ao direito, pela qual juízes e tribunais têm sua atuação determinada pela Constituição e pelas leis. Órgãos judiciais, ensina o conhecimento convencional, não exercem vontade própria, mas concretizam a vontade política majoritária manifestada pelo constituinte ou pelo legislador. A atividade de interpretar e aplicar normas jurídicas é regida por um conjunto de princípios, regras, convenções, conceitos e práticas que dão especificidade à ciência do direito ou dogmática jurídica. Este, portanto, o discurso padrão: juízes são independentes da política e limitam-se a aplicar o direito vigente, de acordo com critérios aceitos pela comunidade jurídica.

\section{Independência do Judiciário}

A independência do Judiciário é um dos dogmas das democracias contemporâneas. Em todos os países que emergiram de regimes autoritários, um dos tópicos essenciais do receituário para a reconstrução do Estado de direito é a organização de um Judiciário que esteja protegido de pressões políticas e que possa interpretar e aplicar a lei com isenção, baseado em técnicas e princípios aceitos pela comunidade jurídica. Independência e imparcialidade como condições para um governo de leis, e não de homens. De leis, e não de 
juízes, fique bem entendido ${ }^{59}$. Para assegurar que assim seja, a Constituição brasileira, por exemplo, confere à magistratura garantias institucionais - que incluem autonomia administrativa e financeira - e funcionais, como a vitaliciedade, inamovibilidade e irredutibilidade de remuneração ${ }^{60}$. Naturalmente, para resguardar a harmonia com outros Poderes, o Judiciário está sujeito a checks and balances e, desde a Emenda Constitucional $\mathrm{n}^{\circ}$ 45, de 2004, ao controle administrativo, financeiro e disciplinar do Conselho Nacional de Justiça. Em uma democracia, todo poder é representativo, o que significa que deve ser transparente e prestar contas à sociedade. Nenhum poder pode estar fora do controle social, sob pena de se tornar um fim em si mesmo, prestando-se ao abuso e a distorções diversas ${ }^{61}$.

\section{Vinculação ao direito posto e à dogmática jurídica}

O mundo do direito tem suas fronteiras demarcadas pela Constituição e seus caminhos determinados pelas leis. Além disso, tem valores, categorias e procedimentos próprios, que pautam e limitam a atuação dos agentes jurídicos, sejam juízes, advogados ou membros do Ministério Público. Pois bem: juízes não inventam o direito do nada. Seu papel é o de aplicar normas que foram positivadas pelo constituinte ou pelo legislador. Ainda quando desempenhem uma função criativa do direito para o caso concreto, deverão fazê-lo à luz dos valores compartilhados pela comunidade a cada tempo. Seu trabalho, portanto, não inclui escolhas livres, arbitrárias ou caprichosas. Seus limites são a vontade majoritária e os valores compartilhados. Na imagem recorrente, juízes de direito são como árbitros desportivos: cabelhes valorar fatos, assinalar faltas, validar gols ou pontos, marcar o tempo regulamentar,

\footnotetext{
59 Registre-se a aguda observação de Dieter Grimm, ex-juiz da Corte Constitucional alemã: "A garantia constitucional de independência judicial protege os juízes da política, mas não protege o sistema constitucional e a sociedade de juízes que, por razões distintas da pressão política direta, estão dispostos a desobedecer ou distorcer a lei (Dieter Grimm, Constitutions, constitutional courts and constitutional interpretation at the interface of law and politics. In: IANCU, Bogdan (ed.). The law/politics distinction in contemporary public law adjudication. Utrecht: Eleven Publishing, 2009, p. 26).

${ }^{60}$ V. Constituição Federal, arts. 95 e 99. Sobre o tema, v. BARROSO, Luís Roberto. Constitucionalidade e legitimidade da criação do Conselho Nacional de Justiça. Interesse Público, Porto Alegre, 2005, v. 6, n. 30, p. 13.

${ }^{61}$ Em texto escrito anteriormente à criação do Conselho Nacional de Justiça, e tendo como pano de fundo disputas politizadas ligadas à privatização e aos planos econômicos, escreveu SANTISO, Carlos. "Economic reform and judicial governance in Brazil: balancing independence with accountability". In: GLOPPEN, Siri; GARGARELLA, Roberto; SKAAR, Elin. Democratization and the judiciary: The Accountability Function of Courts in New Democracies. London: Frank Cass Publishers, 2004, p. 172 e 177: "Excessiva independência tende a gerar incentivos perversos e insular o Judiciário do contexto político e econômico mais amplo, convertendo-o em uma instituição autárquica, incapaz de responder às demandas sociais. (...) Independência sem responsabilidade política (accountability) pode ser parte do problema e não da solução”.
} 
enfim, assegurar que todos cumpram as regras e que o jogo seja justo. Mas não lhes cabe formular as regras ${ }^{62}$. A metáfora já teve mais prestígio, mas é possível aceitar, para não antecipar a discussão do próximo tópico, que ela seja válida para qualificar a rotina da atividade judicial, embora não as grandes questões constitucionais.

Não está em questão, portanto, que as escolhas políticas devem ser feitas, como regra geral, pelos órgãos eleitos, isto é, pelo Congresso e pelo Presidente. Os tribunais desempenham um papel importante na vida democrática, mas não o papel principal. Dois autores contemporâneos utilizaram expressões que se tornaram emblemáticas para demarcar o papel das cortes constitucionais. Ronald Dworkin referiu-se a "fórum de princípios". Em uma sociedade democrática, algumas questões decisivas devem ser tratadas como questões de princípios - morais ou políticos - e não como uma questão de poder político, de vontade majoritária. São elas as que envolvem direitos fundamentais das pessoas, e não escolhas gerais sobre como promover o bem-estar social ${ }^{63}$. Já John Rawls explorou a idéia de "razão pública”. Em uma democracia pluralista, a razão pública consiste na justificação das decisões políticas sobre questões constitucionais essenciais e sobre questões de justiça básica, como os direitos fundamentais. Ela expressa os argumentos que pessoas com formação política e moral diversa podem acatar, o que exclui, portanto, o emprego de doutrinas abrangentes, como as de caráter religioso ou ideológico ${ }^{64}$. Em suma: questões de princípio devem ser decididas, em última instância, por cortes constitucionais, bom base em argumentos de razão pública.

\footnotetext{
${ }^{62}$ Em uma das audiências que antecederam sua confirmação como Presidente da Suprema Corte americana, em setembro de 2005, John G. Roberts Jr. voltou a empregar essa metáfora frequente: "Juízes são como árbitros desportivos (umpires). Eles não fazem as regras; eles as aplicam. O papel de um árbitro, assim como o de um juiz, é muito importante. Eles asseguram que todos joguem de acordo com as regras. Mas é um papel limitado". A passagem está reproduzida em Week in review. New York Times, 12 jul. 2009. V. a íntegra do depoimento, disponível em: http://www.gpoaccess.gov/congress/senate/judiciary/sh109-158/55-56.pdf. Acesso em: 16.mai.2011.

${ }^{63}$ V. DWORKIN, Ronald. A matter of principle. Cambridge: Harvard University Press, 1985, p. 69-71. "A fiscalização judicial assegura que as questões mais fundamentais de moralidade política serão apresentadas e debatidas como questões de princípio, e não apenas de poder político. Essa é uma transformação que não poderá jamais ser integralmente bem-sucedida apenas no âmbito do Legislativo". Por exemplo: a igualdade racial, a igualdade de gênero, a orientação sexual, os direitos reprodutivos, o direito do acusado ao devido processo legal, dentre outras, são questões de princípio, e não de política.

${ }^{64}$ RAWLS, John. Political liberalism. New York: Columbia University Press, 1996, p. 212 e s., especialmente p. 231-40. Nas suas próprias palavras: “(A razão pública) se aplica também, e de forma especial, ao Judiciário e, acima de tudo, à suprema corte, onde haja uma democracia constitucional com controle de constitucionalidade. Isso porque os Ministros têm que explicar e justificar suas decisões, baseadas na sua compreensão da Constituição e das leis e precedentes relevantes. Como os atos do Legislativo e do Executivo não precisam ser justificados dessa forma, o papel especial da Corte a torna um caso exemplar de razão pública”. Para uma crítica da visão de Rawls, v. WALDRON, Jeremy. Public reason and 'justification' in the courtroom. Journal of Law, Philosophy and Culture, 2007, v.1, n.1, p.108.
} 


\section{Limites da separação entre direito e política}

Direito é, certamente, diferente da política. Mas não é possível ignorar que a linha divisória entre ambos, que existe inquestionavelmente, nem sempre é nítida, e certamente não é fixa ${ }^{65}$. Do ponto de vista da teoria jurídica, tem escassa adesão, nos dias que correm, a crença de que as normas jurídicas tragam sempre em si um sentido único, objetivo, válido para todas as situações sobre as quais incidem. E que, assim, caberia ao intérprete uma atividade de mera revelação do conteúdo preexistente na norma, sem desempenhar qualquer papel criativo na sua concretização. Há praticamente consenso, na doutrina contemporânea, de que a interpretação e aplicação do direito envolvem elementos cognitivos e volitivos. Do ponto de vista funcional, é bem de ver que esse papel de intérprete final e definitivo, em caso de controvérsia, é desempenhado por juízes e tribunais. De modo que o Poder Judiciário e, notadamente, o Supremo Tribunal Federal, desfruta de uma posição de primazia na determinação do sentido e do alcance da Constituição e das leis, pois cabe-lhe dar a palavra final, que vinculará os demais Poderes. Essa supremacia judicial quanto à determinação do que é o direito envolve, por evidente, o exercício de um poder político, com todas as suas implicações para a legitimidade democrática ${ }^{66}$.

\section{Parte III}

\section{DIREITO E POLÍTICA: O MODELO REAL}

\section{OS LAÇOS INEVITÁVEIS: A LEI E SUA INTERPRETAÇÃO COMO ATOS DE VONTADE}

No mundo romano-germânico, é comum fazer-se referência ao direito como uma ciência. A afirmação pode ser aceita, ainda que com reserva, se o termo ciência for tomado no sentido de um conjunto organizado de conhecimentos, que guarda uma lógica interna e tem princípios, conceitos e categorias específicos, unificados em uma terminologia própria. Mas é intuitiva a distinção a ser feita em relação às ciências da natureza. Essas últimas são domínios que lidam com fenômenos que se ordenam independentemente da vontade humana, seja o legislador, o público em geral ou o intérprete. São ciências que se destinam a explicar o que lá

\footnotetext{
${ }^{65}$ V. MENDONÇA, Eduardo. A inserção da jurisdição constitucional na democracia: algum lugar entre o direito e a política. Revista de direito do Estado, Rio de Janeiro, v. 4, n.13, p. 212.

${ }^{66}$ Sobre o conceito de legitimidade e sua evolução, v. MOREIRA NETO, Diogo de Figueiredo. Quatro paradigmas do direito administrativo pós-moderno. Rio de Janeiro: Editora Fórum, 2008, p. 33-47.
} 
já está. Sem pretender subestimar complexidades epistemológicas, são domínios em que o anseio científico por objetividade e comprovação imparcial se realiza mais intensamente. Já o direito se insere no campo das ciências sociais e tem, sobretudo, uma pretensão prescritiva: ele procura moldar a vida de acordo com suas normas. E normas jurídicas não são reveladas, mas, sim, criadas por decisões e escolhas políticas, tendo em vista determinadas circunstâncias e visando determinados fins. E, por terem caráter prospectivo, precisarão ser interpretadas no futuro, tendo em conta fatos e casos concretos.

Como consequência, tanto a criação quanto a aplicação do direito dependem da atuação de um sujeito, seja o legislador ou o intérprete. A legislação, como ato de vontade humana, expressará os interesses dominantes - ou, se se preferir, o interesse público, tal como compreendido pela maioria, em um dado momento e lugar. E a jurisdição, que é a interpretação final do direito aplicável, expressará, em maior ou menor intensidade, a compreensão particular do juiz ou do tribunal acerca do sentido das normas. Diante de tais premissas, é possível extrair uma conclusão parcial bastante óbvia, ainda que frequentemente encoberta: o mantra repetido pela comunidade jurídica mais tradicional de que o direito é diverso da política exige um complemento. É distinto, sim, e por certo; mas não é isolado dela. Suas órbitas se cruzam e, nos momentos mais dramáticos, se chocam, produzindo vítimas de um ou dos dois lados: a justiça e a segurança jurídica, que movem o direito; ou a soberania popular e a legitimidade democrática, que devem conduzir a política. A seguir se exploram diferentes aspectos dessa relação. Alguns deles são ligados à teoria do direito e da interpretação, e outros às circunstâncias dos juízes e órgãos julgadores.

II. A INTERPRETAÇÃO JURÍDICA E SUAS COMPLEXIDADES: O ENCONTRO NÃO MARCADO ENTRE O DIREITO E A POLÍTICA

\section{A linguagem aberta dos textos jurídicos}

A linguagem jurídica, como a linguagem em geral, utiliza-se de signos que precisam ser interpretados. Tais signos, muitas vezes, possuem determinados sentidos consensuais ou de baixo grau de controvérsia. Embora nem sempre as coisas sejam simples como parecem, há pouca dúvida do que signifique município, orçamento ou previdência complementar. Mas a Constituição se utiliza, igualmente, de inúmeras cláusulas abertas, que incluem conceitos jurídicos indeterminados e princípios. Calamidade pública, relevância e urgência ou crime político são conceitos que transmitem uma ideia inicial de sentido, mas que precisam ser 
integrados à luz dos elementos do caso concreto. E, em relação a eles, embora possam existir certezas positivas e negativas sobre o que significam ou deixam de significar, é indiscutível que há uma ampla área de penumbra que se presta a valorações que não poderão refugir a algum grau de subjetividade. $\mathrm{O}$ fenômeno se repete com maior intensidade quando se trate de princípios constitucionais, com sua intensa carga axiológica, como dignidade da pessoa humana, moralidade administrativa ou solidariedade social. Também aqui será impossível falar em sentidos claros e unívocos. Na interpretação de normas cuja linguagem é aberta e elástica, o direito perde muito da sua objetividade e abre espaço para valorações do intérprete. $\mathrm{O}$ fato de existir consenso de que ao atribuir sentido a conceitos indeterminados e a princípios não deve o juiz utilizar-se dos seus próprios valores morais e políticos não elimina riscos e complexidades, funcionando como uma bússola de papel.

\section{Os desacordos morais razoáveis}

Além dos problemas de ambiguidade da linguagem, que envolvem a determinação semântica de sentido da norma, existem, também, em uma sociedade pluralista e diversificada, o que se tem denominado de desacordo moral razoável ${ }^{67}$. Pessoas bem intencionadas e esclarecidas, em relação a múltiplas matérias, pensam de maneira radicalmente contrária, sem conciliação possível. Cláusulas constitucionais como direito à vida, dignidade da pessoa humana ou igualdade dão margem a construções hermenêuticas distintas, por vezes contrapostas, de acordo com a pré-compreensão do intérprete. Esse fenômeno se revela em questões que são controvertidas em todo o mundo, inclusive no Brasil, como, por exemplo, interrupção de gestação, pesquisas com células-tronco embrionárias, eutanásia/ortotanásia, uniões homoafetivas, em meio a inúmeras outras. Nessas matérias, como regra geral, o papel do direito e do Estado deve ser o de assegurar que cada pessoa possa viver sua autonomia da vontade e suas crenças. Ainda assim, inúmeras complexidades surgem, motivadas por visões filosóficas e religiosas diversas.

\section{As colisões de normas constitucionais}

\footnotetext{
${ }^{67}$ Sobre o tema, na literatura mais recente, v. MCMAHON, Christopher. Reasonable disagreement: a theory of political morality. Cambridge: Cambridge University Press, 2009; e TERSMAN, Folke. Moral disagreement. Cambridge: Cambridge. University Press, 2006.
} 
Constituições são documentos dialéticos e compromissórios, que consagram valores e interesses diversos, que eventualmente entram em rota de colisão. Essas colisões podem se dar, em primeiro lugar, entre princípios ou interesses constitucionalmente protegidos. É o caso, por exemplo, da tensão entre desenvolvimento nacional e proteção do meio-ambiente ou entre livre-iniciativa e repressão ao abuso do poder econômico. Também é possível a colisão entre direitos fundamentais, como a liberdade de expressão e o direito de privacidade, ou entre a liberdade de reunião e o direito de ir e vir (no caso, imagine-se, de uma passeata que bloqueie integralmente uma via de trânsito essencial). Por fim, é possível cogitar de colisão de direitos fundamentais com certos princípios ou interesses constitucionalmente protegidos, como o caso da liberdade individual, de um lado, e a segurança pública e a persecução penal, de outro. Em todos esses exemplos, à vista do princípio da unidade da Constituição, o intérprete não pode escolher arbitrariamente um dos lados, já que não há hierarquia entre normas constitucionais. De modo que ele precisará demonstrar, argumentativamente, à luz dos elementos do caso concreto, mediante ponderação e uso da proporcionalidade, que determinada solução realiza mais adequadamente a vontade da Constituição, naquela situação específica.

Todas essas hipóteses referidas acima - ambiguidade da linguagem, desacordo moral e colisões de normas - recaem em uma categoria geral que tem sido referida como casos difíceis (hard cases ${ }^{68}$. Nos casos fáceis, a identificação do efeito jurídico decorrente da incidência da norma sobre os fatos relevantes envolve uma operação simples, de mera subsunção. O proprietário de um imóvel urbano deve pagar imposto predial. A Constituição não permite ao Chefe do Executivo um terceiro mandato. Já os casos difíceis envolvem situações para as quais não existe uma solução acabada no ordenamento jurídico. Ela precisa ser construída argumentativamente, por não resultar do mero enquadramento do fato à norma. Pode um artista, em nome do direito de privacidade, impedir a divulgação de sua biografia, escrita por um pesquisador? Pode o autor de uma ação de investigação de paternidade exigir que o indigitado pai se submeta coativamente a exame de DNA? Em ambos os casos, que envolvem questões constitucionais - privacidade, liberdade de expressão, direitos da personalidade, liberdade individual - a solução para a disputa não é encontrável pré-pronta no sistema jurídico: ela precisa ser desenvolvida justificadamente pelo intérprete.

\footnotetext{
${ }^{68}$ Sobre o tema, v. DWORKIN, Ronald. Taking rights seriously. 16. ed. Cambridge, Harvard University Press, 1997, p. 81 e s.; e BARAK, Aharon. The judge in a democracy. Princeton: Princeton University Press, 2006, p. xiii e s.
} 


\section{A interpretação constitucional e seus métodos}

Em todas as hipóteses referidas acima, envolvendo casos difíceis, o sentido da norma precisará ser fixado pelo juiz. Como se registrou, são situações em que a solução não estará pronta em uma prateleira jurídica e, portanto, exigirá uma atuação criativa do intérprete, que deverá argumentativamente justificar seu itinerário lógico e suas escolhas. Se a solução não está integralmente na norma, o juiz terá de recorrer a elementos externos ao direito posto, em busca do justo, do bem, do legítimo. Ou seja, sua atuação terá de se valer da filosofia moral e da filosofia política. Mesmo admitida esta premissa - a de que o juiz, ao menos em certos casos, precisa recorrer a elementos extrajurídicos -, ainda assim se vai verificar que diferentes juízes adotam diferentes métodos de interpretação. Há juízes que pretendem extrair da Constituição suas melhores potencialidades, realizando na maior extensão possível os princípios e direitos fundamentais. Há outros que entendem mais adequado não ler na Constituição o que nela não está de modo claro ou expresso, prestando maior deferência ao legislador ordinário ${ }^{69}$. Uma pesquisa empírica revelará, sem surpresa, que os mesmos juízes nem sempre adotam os mesmos métodos de interpretação ${ }^{70}$. Seu método ou filosofia judicial é mera racionalização da decisão que tomou por outras razões ${ }^{71}$. E aí surge uma nova variável: o resultado baseado não no princípio, mas no fim, no resultado ${ }^{72}$.

\footnotetext{
${ }^{69}$ SUNSTEIN, Cass. Radicals in robes: Why extreme Right-wing courts are wrong for américa. New York: Basic Books, 2005, identifica quatro abordagens no debate constitucional: perfeccionismo, majoritarianismo, minimialismo e fundamentalismo. O perfeccionismo, adotado por muitos juristas progressistas, quer fazer da Constituição "o melhor que ela possa ser". O majoritarianismo pretende diminuir o papel da Suprema Corte e favorecer o processo político democrático, cujo centro de gravidade estaria no Legislativo. O minimalismo é cético acerca de teorias interpretativas e acredita em decisões menos abrangentes, focadas no caso concreto e não em proposições amplas. $\mathrm{O}$ fundamentalismo procura interpretar a Constituição dando-lhe o sentido que tinha quando foi ratificada. Para uma dura crítica ao minimalismo defendido por Sunstein, v. DWORKIN, Ronald. Looking for Cass Sunstein. The New York Review of Books 56, 30 abr. 2009 (também disponível em: http://www.nybooks.com/articles/22636). Acesso em: 16.mai.20011.
}

\footnotetext{
${ }^{70}$ Sobre o ponto, v. SILVA, Alexandre Garrido da. Minimalismo, democracia e expertise: o Supremo Tribunal Federal diante de questões políticas e científicas complexas. Revista de direito do Estado, Rio de Janeiro, out./dez.2008, v. 3, n. 12, p. 139: "É importante destacar que não há um magistrado que em sua prática jurisdicional seja sempre minimalista ou perfeccionista. Nos casos da fidelidade partidária, da cláusula de barreira e da inelegibilidade, por exemplo, o Min. Eros Grau assumiu um posicionamento nitidamente minimalista e formalista, ao passo que no caso do amianto aproximou-se, conforme foi visto, do modelo perfeccionista".
}

${ }^{71}$ Para essa visão cética, v. POSNER, Richard A.. How judges think. Cambridge: Harvard University Press, 2008 , p. 13, onde registrou que as filosofias judiciais "são ou racionalizações para decisões tomadas por outros fundamentos ou armas retóricas".

${ }^{72}$ V., ainda uma vez, SILVA, Alexandre Garrido da. Minimalismo, democracia e expertise: o Supremo Tribunal Federal diante de questões políticas e científicas complexas. Revista de direito do Estado, Rio de Janeiro, out./dez.2008, v. 3, n. 12, p. 139: "Frequentemente, os juízes tendem a fazer um uso estratégico dos modelos anteriormente descritos tendo em vista fins previamente escolhidos, ou seja, optam pragmaticamente pelo 
Nesse ponto, impossível não registrar a tentação de se abrir espaço para o debate acerca de uma das principais correntes filosóficas do direito contemporâneo: o pragmatismo jurídico, com seu elemento constitutivo essencial, que é o consequencialismo. Para essa concepção, as consequências e resultados práticos das decisões judiciais, assim em relação ao caso concreto como ao sistema como um todo, devem ser o fator decisivo na atuação dos juízes e tribunais ${ }^{73}$. O pragmatismo jurídico afasta-se do debate filosófico em geral, seja moral ou político - inclusive o que mobilizou jusnaturalistas e positivistas em torno da resposta à pergunta "o que é o direito?" - e se alinha a um empreendimento teórico distinto, cuja indagação central é: "como os juízes devem decidir?"74. Não é o caso, aqui, de se objetar que uma coisa não exclui a outra. A realidade incontornável, na circunstância presente, é que o desvio que conduz ao debate sobre o pragmatismo jurídico não poderá ser feito no âmbito desse trabalho. E isso não apenas por afastá-lo do seu eixo central, como também pela complexidade da tarefa de qualificar o que seja pragmatismo jurídico e de sistematizar as diferentes correntes que reivindicam o rótulo.

\section{O JUIZ E SUAS CIRCUNSTÂNCIAS: INFLUÊNCIAS POLÍTICAS EM UM JULGAMENTO ${ }^{75}$}

No modelo idealizado, o direito é imune às influências da política, por força de diferentes institutos e mecanismos. Basicamente, eles consistiriam: na independência do Judiciário e na vinculação do juiz ao sistema jurídico. A independência se manifesta, como

modelo mais adequado para a resolução do problema enfrentado no caso concreto". Sobre o consequencialismo - isto é, o processo decisório fundado no resultado -, v. ARGUELLES, Diego Werneck. Deuses pragmáticos, mortais formalistas: a justificação consequencialista das decisões judiciais. Dissertação de mestrado em direito Público, Universidade do Estado do Rio de Janeiro - UERJ. Rio de Janeiro, 2006.

${ }^{73}$ Sobre o pragmatismo filosófico, v. RORTY, Richard. Consequences of pragmatism. Minneapolis: University of Minnesota Press, 1982. Sobre o pragmatismo jurídico, no debate norte-americano, vejam-se, dentre muitos: POSNER, Richard. Law, pragmatism and democracy. Cambridge: Harvard University Press, 2003; e COLEMAN, Jules. The practice of principle: in defence of a pragmatic approach to legal theory. New York: Oxford University Press, 2001. Em língua portuguesa, v. ARGUELHES, Diego Werneck; LEAL, Fernando. "Pragmatismo como [meta] teoria normativa da decisão judicial: caracterização, estratégia e implicações". In: SARMENTO, Daniel (coord.). Filosofia e teoria constitucional contemporânea. Rio de Janeiro: Lumen Juris, 2009; POGREBINSCHI, Thamy. Pragmatismo: teoria social e política. Rio de Janeiro: Relume Dumará, 2005; e SOUZA NETO, Cláudio Pereira de. "A interpretação constitucional contemporânea entre o construtivismo e o pragmatismo". In: MAIA, Antonio Cavalcanti; MELO, Carolina de Campos; CITTADINO, Gisele; POGREBINSCHI, Thamy (Org.). Perspectivas atuais da filosofia do direito. Rio de Janeiro, Lumens Júris, 2005.

${ }^{74}$ Sobre esse ponto específico, v. ARGUELHES, Diego Werneck; LEAL, Fernando. "Pragmatismo como [meta] teoria normativa da decisão judicial: caracterização, estratégia e implicações”. In: SARMENTO, Daniel (coord.). Filosofia e teoria constitucional contemporânea. Rio de Janeiro: Lumen Juris, 2009, p. 175 e 187.

${ }^{75}$ As idéias que se seguem beneficiaram-se, intensamente, das formulações contidas em: FRIEDMAN, Barry. The politics of judicial review. Texas Law Review, Austin, 2005, v. 84, n. 2, p.257. 
assinalado, em garantias institucionais - como a autonomia administrativa e financeira - e garantias funcionais dos juízes, como a vitaliciedade, a inamovibilidade e a irredutibilidade de subsídios. Como regra geral, a investidura e a ascensão na carreira da magistratura se dá por critérios técnicos ou por valorações interna corporis. Nos casos em que há participação política na nomeação de magistrados para tribunais, ela se esgota após a posse, pois a permanência vitalícia do magistrado no cargo já não dependerá de qualquer novo juízo político. A autonomia e especificidade do universo jurídico, por sua vez, consistem em um conjunto de doutrinas, categorias e princípios próprios, manejados por juristas em geral - aí incluídos juízes, advogados, membros do Ministério Público e demais participantes do processo jurídico e judicial - que não se confundem com os da política. Trata-se de um discurso e de um código de relação diferenciados. Julgar é distinto de legislar e de administrar. Juízes não criam o direito nem definem as ações administrativas. Seu papel é aplicar a Constituição e as leis, valendo-se de um conjunto de institutos consolidados de longa data, sendo que a jurisprudência desempenha, crescentemente, um papel limitador dessa atuação, pela vinculação aos precedentes. Direito e política, nessa visão, constituem mundos apartados.

Há um modelo oposto a esse, que se poderia denominar de modelo cético, que descrê da autonomia do direito em relação à política e aos fenômenos sociais em geral. Esse é o ponto de vista professado por movimentos teóricos de expressão, como o realismo jurídico, a teoria crítica e boa parte das ciências sociais contemporâneas. Todos eles procuram descrever o mundo jurídico e as decisões judiciais como são, e não como deveriam ser. Afirmam, assim, que a crença na objetividade do direito e a existência de soluções prontas no ordenamento jurídico não passam de mitos. Não é verdade que o direito seja um sistema de regras e de princípios harmônicos, de onde um juiz imparcial e apolítico colhe as soluções adequadas para os problemas, livre de influências externas. Essa é uma fantasia do formalismo jurídico. Decisões judiciais refletem as preferências pessoais dos juízes, proclama o realismo jurídico; são essencialmente políticas, verbera a teoria crítica; são influenciadas por inúmeros fatores extrajurídicos, registram os cientistas sociais. Todo caso difícil pode ter mais de uma solução razoável construída pelo intérprete, e a solução que ele produzirá será, em última análise, aquela que melhor atenda a suas preferências pessoais, sua ideologia ou outros fatores externos, como os de natureza institucional. Ele sempre agirá assim, tenha ou não consciência do que está fazendo.

O modelo real, como não é difícil de intuir, terá uma dose razoável de cada uma das visões extremas descritas acima. O direito pode e deve ter uma vigorosa pretensão de 
autonomia em relação à política. Isso é essencial para a subsistência do conceito de Estado de direito e para a confiança da sociedade nas instituições judiciais. A realidade, contudo, revela que essa autonomia será sempre relativa. Existem razões institucionais, funcionais e humanas para que seja assim. Decisões judiciais, com frequência, refletirão fatores extrajudiciais. Dentre eles incluem-se os valores pessoais e ideológicos do juiz, assim como outros elementos de natureza política e institucional. Por longo tempo, a teoria do direito procurou negar esse fato, a despeito das muitas evidências. Pois bem: a energia despendida na construção de um muro de separação entre o direito e a política deve voltar-se agora para outra empreitada ${ }^{76}$. Cuida-se de entender melhor os mecanismos dessa relação intensa e inevitável, com o propósito relevante de preservar, no que é essencial, a especificidade e, sobretudo, a integridade do direito ${ }^{77}$. Pois é justamente este o objetivo do presente tópico: analisar alguns desses elementos metajurídicos que influenciam ou podem influenciar as decisões judiciais. Confira-se a sistematização a seguir.

\section{Valores e ideologia do juiz}

Como assinalado, o realismo jurídico, um dos mais importantes movimentos teóricos do direito no século XX, contribuiu decisivamente para a superação do formalismo jurídico e da crença de que a atividade judicial seria mecânica, acrítica e unívoca. Enfatizando que o direito tem ambiguidades e contradições, o realismo sustentava que a lei não é o único - e, em muitos casos, sequer o mais importante - fator a influenciar uma decisão judicial. Em uma multiplicidade de hipóteses, é o juiz que faz a escolha do resultado, à luz de suas intuições, personalidade, preferências e preconceitos ${ }^{78}$. Em linha análoga, mas dando proeminência

\footnotetext{
${ }^{76}$ V. FRIEDMAN, Barry. The politics of judicial review. Texas Law Review, Austin, 2005, v. 84, n. 2 , p. 267 e p. 269, onde averbou: "Se, como os juristas vêm crescentemente reconhecendo, direito e política não podem ser mantidos separados, ainda precisamos de uma teoria que possa integrá-los, sem abrir mão dos compromissos com o Estado de direito que esta sociedade tanto preza".

${ }^{77}$ Sobre a ideia de direito como integridade, v. DWORKIN, Ronald. O império do direito. São Paulo: Martins Fontes, 1999, p. 271-331.

${ }^{78}$ Sobre o tema, v. FISHER III, William W. et. Al (eds.). American Legal realism. New York: Oxford University Press, 1993, 164-5; HOLMES, JR., Oliver Wendel. The path of the law. Harvard Law Review, Cambridge, 1897, v. 10, n. 8, p. 457; LLEWELLYN, Karl. Some realism about realism - responding to Dean Pound. Harvard Law Review, 1931, v. 44, p. 1222; e FRANK, Jerome. What courts do in fact. Illinois Law Review, 1932, v. 26, p. 645. Para uma análise da incorporação de ideias do realismo jurídico americano no Brasil, sua "assimilação antropofágica", v. GARCIA NETO, Paulo Macedo. A influência do realismo jurídico americano no direito constitucional brasileiro. Dissertação de mestrado, Universidade de São Paulo.
} 
absoluta ao elemento político, a teoria crítica ${ }^{79}$, no mundo romano-germânico, e os critical legal studies, nos Estados Unidos, sustentaram que decisões judiciais não passam de escolhas políticas, encobertas por um discurso que procura exibir neutralidade ${ }^{80}$. Tanto o realismo quanto a teoria crítica refluíram drasticamente nas últimas décadas, mas deixaram uma marca indelével no pensamento jurídico contemporâneo ${ }^{81}$. Mais recentemente, um conjunto de estudos empíricos, oriundos, sobretudo, da ciência política, recolocaram no centro do debate jurídico o tema dos valores, preferências e ideologia do juiz na determinação do resultado de casos judiciais ${ }^{82}$.

Há, de fato, quem sustente ser mais fácil saber um voto ou uma decisão pelo nome do juiz do que pela tese jurídica aplicável ${ }^{83}$. Essa visão cética acarreta duas consequências negativas: deslegitima a função judicial e libera os juízes para fazerem o que quiserem ${ }^{84}$. Há uma razão subjetiva e outra objetiva que se pode opor a esse ponto de vista. A primeira: é possível assumir, como regra geral, que juízes verdadeiramente vocacionados têm como motivação primária e principal a interpretação adequada do direito vigente, com a valoração imparcial dos elementos fáticos e jurídicos relevantes ${ }^{85}$. Não se deve minimizar esse sentido de dever que move as pessoas de bem em uma sociedade civilizada. Em segundo lugar, o direito - a Constituição, as leis, a jurisprudência, os elementos e métodos de interpretação sempre desempenhará uma função limitadora. O discurso normativo e a dogmática jurídica são autônomos em relação às preferências pessoais do julgador. Por exemplo: o desejo de punir uma determinada conduta não é capaz de superar a ocorrência de prescrição. O ímpeto

\footnotetext{
${ }^{79}$ V. MIAILLE, Michel. Introdução crítica ao direito. 2. ed. Lisboa: Editorial Estampa, 1989; CÁRCOVA, Carlos Maria. Teorías jurídicas alternativas: escritos sobre derecho y política. Buenos Aires: Centro Editor de América Latina, 1993; e COELHO, Luiz Fernando. Teoria crítica do direito. 2. ed. Porto Alegre: Sergio Antonio Fabris Editor, 1991.

${ }^{80}$ V. KENNEDY, Duncan. Legal education and the reproduction of hierarchy. Journal of Legal Education, 1982, v. 32, n. 4, p. 591; TUSHNET, Mark. Critical legal studies: a political history. Yale Law Journal, 1991 , v. 100 , p. 1515.

${ }^{81}$ V. WALDRON, Jeremy. Public reason and 'justification' in the courtroom. Journal of Law, Philosophy and Culture. 2007, v.1, n.1, p. 127: "A maioria dos juristas contemporâneos não aceita a visão crítica do realismo jurídico".

${ }^{82}$ V. SUNSTEIN, Cass; SCHKADE, David; ELLMAN, Lisa M.; SAWICKI, Andres. Are judges political? An empirical analysis of the Federal Judiciary. Washington, DC: Brookings Institute Press, 2006; e MILES, Thomas J.; SUNSTEIN, Cass. The new legal realism. Public Law and Legal Theory Working Paper. Dezembro de 2007, n. 191. Disponível em: http://ssrn.com/abstract_id=1070283. Acesso em: 16.ago.2009.

${ }^{83}$ BORK, Robert H.. Coercing virtue: the worldwide rule of judges. Washington, DC: AEI Press, 2003, p. 9.

${ }^{84}$ DORF, Michael. No litmus test: Law versus politics in the twentieth century. Lanham: Rowman \& Littlefield Publishers, 2006.

${ }^{85}$ FRIEDMAN, Barry. The politics of judicial review. Texas Law Review, Austin, 2005, v. 84, n. 2, p.270.
} 
de conhecer e julgar uma causa não muda a regra sobre legitimação ativa ou sobre prejudicialidade ${ }^{86}$. De modo que o sentimento pessoal de cumprir o próprio dever e a força vinculante do direito são elementos decisivos na atuação judicial. Mas há que se reconhecer que não são únicos.

Com efeito, a observação atenta, a prática política e pesquisas empíricas confirmam o que sempre foi possível intuir: os valores pessoais e a ideologia dos juízes influenciam, em certos casos de maneira decisiva, o resultado dos julgamentos. Por exemplo: na apreciação da constitucionalidade das pesquisas com células-tronco embrionárias, a posição contrária à lei que as autorizava foi liderada por Ministro ligado historicamente ao pensamento e à militância católica $^{87}$, sendo certo que a Igreja se opõe às investigações científicas dessa natureza ${ }^{88}$. Nos Estados Unidos, fez parte da estratégia conservadora, iniciada com a posse de Ronald Reagan, em 1981, nomear para a Suprema Corte Ministros que pudessem reverter decisões judiciais consideradas progressistas, em temas como ações afirmativas, aborto e direitos dos acusados em processos criminais ${ }^{89}$. Inúmeras pesquisas, no Brasil ${ }^{90}$ e nos Estados Unidos ${ }^{91}$, confirmam que as preferências políticas dos juízes constituem uma das variáveis mais relevantes para as decisões judiciais, notadamente nos casos difíceis. É de se registrar que o processo psicológico que conduz a uma decisão pode ser consciente ou inconsciente ${ }^{92}$.

\footnotetext{
${ }^{86}$ Foi o que ocorreu, por exemplo, em ação direta de inconstitucionalidade em que se questionava lei que, supostamente, impediria o reconhecimento das uniões estáveis homoafetivas como entidade familiar. O Ministro Relator, claramente contrariado, viu-se na contingência de extinguir a ação, pois a superveniência do novo Código Civil revogou a lei impugnada (STF, DJ 9 fev. 2006, ADI 3300 MC/DF, Rel. Min. Celso de Mello, decisão monocrática). O mesmo se passou em habeas corpus no qual se discutia a legitimidade da interrupção da gestação na hipótese de feto anencefálico. O Relator chegou a divulgar o seu voto favorável ao direito de escolha da mulher, mas a ocorrência do parto, seguido do óbito, anteriormente ao julgamento, impediu a sua realização (STF, DJ 25 jun.2004, HC 84.025-6/RJ, Rel. Min. Joaquim Barbosa).

${ }^{87}$ A referência é ao saudoso Ministro Carlos Alberto Menezes Direito, falecido em setembro de 2009.

${ }^{88} \mathrm{Na}$ Adin $\mathrm{n}^{\circ} 3.510$, na qual se questionou a constitucionalidade do dispositivo legal que autorizava as pesquisas, a Conferência Nacional dos Bispos do Brasil, representada pelo Professor Ives Gandra da Silva Martins, foi admitida como amicus curiae e pediu a procedência da ação.

${ }^{89}$ POST, Robert; SIEGEL, Reva. Roe rage: democratic constitutionalism and backlash, Harvard Civil RightsCivil Liberties Law Review, Cambridge, 2007, n.42, p. 9: "É bem documentado que o Departamento de Justiça, durante o Governo Reagan, de maneira pré-ordenada e bem-sucedida utilizou as nomeações de juízes para alterar as práticas então predominantes em termos de interpretação constitucional".
}

${ }^{90}$ SILVA, Alexandre Garrido da.. Minimalismo, democracia e expertise: o Supremo Tribunal Federal diante de questões políticas e científicas complexas. Revista de direito do Estado, Rio de Janeiro, out./dez.2008, v. 3, n. 12, p. 107.

${ }^{91}$ RUGER, Theodore W.; KIM, Pauline T.; MARTIN, Andrew D.; e QUINN, Kevin M.. The Supreme Court Forecasting Project: legal and political science approaches to predicting Supreme Courte decisionmaking, Columbia Law Review, Columbia, 2004, n. 104, p. 1150.

92 Ao produzir uma decisão, o juiz atua dentro de um universo cognitivo próprio, que inclui sua formação moral e intelectual, suas experiências passadas, sua visão de mundo e suas crenças. Tais fatores podem levá-lo, inconscientemente, a desejar um resultado e procurar realizá-lo. Tal fenômeno é diverso do que se manifesta na 
Note-se que no Brasil, ao contrário dos Estados Unidos, o carimbo político é menos relevante ou, no mínimo, menos visível, na medida em que a maior parte dos cargos no Judiciário são preenchidos mediante concurso público e promoções internas ${ }^{93}$. Mas não é este o caso das nomeações para o Supremo Tribunal Federal, em que os parâmetros constitucionais são vagos - reputação ilibada e notável saber jurídico - e a escolha pessoal do Presidente é o fator mais importante, sem embargo da aprovação pelo Senado Federal. Na literatura norte-americana, tem sido destacada a importância do gênero e da raça na determinação de certos padrões decisórios do juiz. No caso brasileiro, em tribunais superiores, em geral, e no STF, em particular, a origem profissional do Ministro imprime características perceptíveis na sua atuação judicial: Ministros que vêm da Magistratura, do Ministério Público, da advocacia privada, da advocacia pública ou da academia tendem a refletir, no exercício da jurisdição, a influência de experiências pretéritas ${ }^{94}$. Note-se, todavia, em desfecho do tópico, que eventuais preferências políticas do juiz são contidas não apenas por sua subordinação aos sentidos mínimos das normas constitucionais e legais, como também por fatores extrajudiciais, dentre os quais se podem destacar: a interação com outros atores políticos e institucionais, a perspectiva de cumprimento efetivo da decisão, as circunstâncias internas dos órgãos colegiados e a opinião pública.

\section{Interação com outros atores políticos e institucionais}

Como se vem enfatizando até aqui, decisões judiciais são influenciadas por fatores múltiplos. Tribunais não são guardiães de um direito que não sofre o influxo da realidade, das maiorias políticas e dos múltiplos atores de uma sociedade plural. Órgãos, entidades e pessoas que se mobilizam, atuam e reagem. Dentre eles é possível mencionar, exemplificativamente, os Poderes Legislativo e Executivo, o Ministério Público, os Estados da Federação e entidades

\footnotetext{
vontade consciente e deliberada de produzir determinado resultado, ainda que não seja o que se considera juridicamente melhor, com o propósito de agradar a quem quer que seja ou para a satisfação de sentimento pessoal. Nessa segunda hipótese, como intuitivo, a conduta não será legítima. Sobre o ponto, v. TAMANAHA, Brian Z.. Beyond the formalist-realist divide: the role of politics in judging. Princeton and Oxford: Princeton University Press, 2010, p. 187-8.

${ }^{93}$ Nos EUA, os juízes federais são indicados pelo Presidente da República e aprovados pelo Senado. No plano estadual, muitos são eleitos e outros são nomeados.

${ }^{94}$ Um exemplo, colhido na composição atual do STF: Ministros que têm sua origem funcional no Ministério Público - como os Ministros Joaquim Barbosa e Ellen Gracie - têm uma visão mais rígida em matéria penal do que os que vêm da advocacia privada ou da academia, como Carlos Ayres Britto e Eros Grau.
} 
da sociedade civil. Todos eles se manifestam, nos autos ou fora deles, procurando fazer valer seus direitos, interesses e preferências. Atuam por meios formais e informais. E o Supremo Tribunal Federal, como a generalidade das cortes constitucionais, não vive fora do contexto político-institucional sobre o qual sua atuação repercute. Diante disso, o papel e as motivações da Corte sofrem a influência de fatores como, por exemplo: a preservação e, por vezes, a expansão de seu próprio poder; a interação com outros Poderes, instituições ou entes estatais; e as consequências práticas de seus julgados, inclusive e notadamente, a perspectiva de seu efetivo cumprimento.

\subsection{Preservação ou expansão do poder da Corte}

O primeiro impulso natural do poder é a auto-conservação. É intuitivo, assim, que um tribunal, em suas relações com os outros atores políticos, institucionais ou sociais, procure demarcar e preservar seu espaço de atuação e sua autoridade, quer pelo acolhimento de reclamações ${ }^{95}$, quer pela reafirmação de sua jurisprudência. Alguns exemplos comprovam o argumento. Após haver cancelado a Súmula no 394, excluindo do foro privilegiado os agentes públicos que deixassem o exercício da função ${ }^{96}$, o STF invalidou lei editada pelo Congresso Nacional que restabelecia a orientação anterior. $\mathrm{O}$ acórdão considerou haver usurpação de sua função de intérprete final da Constituição ${ }^{97}$. Em outro caso, o STF considerou inconstitucional dispositivo legal que impedia a progressão de regime em caso de crime hediondo ${ }^{98}$. Decisão do juiz de direito de Rio Branco, no Acre, deixou de aplicar a nova orientação, sob o argumento de que a declaração de inconstitucionalidade fora incidental e não produzia efeitos vinculantes. A Corte reagiu, e não apenas desautorizou o pronunciamento específico do magistrado estadual, como deu início a uma discussão de mais largo alcance sobre a

\footnotetext{
${ }^{95}$ A reclamação é o remédio jurídico previsto na Constituição e regulamentado pela Lei $n^{\circ} 8.038 / 90$, pela Lei $n^{\circ}$ 11.417/06 e pelo Regimento Interno do Supremo Tribunal Federal, cujo objeto é a preservação da competência da Corte, a garantia da autoridade de suas decisões e a observância do entendimento consolidado em súmula vinculante $\left(\mathrm{CF} / 88\right.$, arts. 102, I, $l$, e 103-A, § $\left.3^{\circ}\right)$.

96 Súmula n. 394: “Cometido o crime durante o exercício funcional, prevalece a competência especial por prerrogativa de função, ainda que o inquérito ou a ação penal sejam iniciados após a cessação daquele exercício". O cancelamento se deu em decisão proferida em 1999. V. STF, DJ 9 nov. 2001, QO no Inq 687/DF, Rel. Min. Sydney Sanches.

${ }^{97}$ STF, DJ 19 dez. 2006, ADIn 2.797, Rel. Min. Sepúlveda Pertence.

98 STF, DJ 1 set.2006, HC 82.959, Rel. Min. Marco Aurélio. Decisão constante do sítio do STF: http://www.stf.jus.br/portal/diarioJustica/verDiarioProcesso.asp?numDj=169\&dataPublicacaoDj=01/09/2006\&n umProcesso $=82959 \&$ siglaClasse $=\mathrm{HC} \& \operatorname{codRecurso}=0 \&$ tipoJulgamento $=\mathrm{M} \& \operatorname{codCapitulo}=5 \&$ numMateria $=27 \& \mathrm{c}$ odMateria=1).
} 
atribuição de efeitos vinculantes e erga omnes à sua decisão de inconstitucionalidade, mesmo que no controle incidental, retirando do Senado a atribuição de suspender a lei considerada inválida $^{99}$. Um terceiro e último exemplo: após haver concedido habeas corpus a um banqueiro, preso temporariamente ao final de uma polêmica operação policial, o STF considerou afronta à Corte a decretação, horas depois, de nova prisão, dessa vez de natureza preventiva, ordenada pelo mesmo juiz, e concedeu um segundo habeas corpus $^{100}$.

O segundo impulso natural do poder é a expansão ${ }^{101}$. No caso brasileiro, esse movimento de ampliação do Poder Judiciário, particularmente do Supremo Tribunal Federal, tem sido contemporâneo da retração do Legislativo, que passa por uma crise de funcionalidade e de representatividade. Nesse vácuo de poder, fruto da dificuldade de o Congresso Nacional formar maiorias consistentes e legislar, a corte suprema tem produzido decisões que podem ser reputadas ativistas, tal como identificado o fenômeno em tópico anterior $^{102}$. Exemplos emblemáticos e sempre lembrados são os dos julgamentos da fidelidade partidária - em que o STF criou, por interpretação do princípio democrático, uma nova hipótese de perda de mandato parlamentar ${ }^{103}$ - e do nepotismo, em que a Corte, com base na interpretação dos princípios constitucionais da moralidade e da impessoalidade, estabeleceu a vedação do nepotismo nos três Poderes ${ }^{104}$. Ações como as que tratam da legitimidade da

${ }^{99} \mathrm{STF}, \mathrm{Rcl} \mathrm{n}^{\mathrm{o}}$ 4.335, Rel. Min. Gilmar Mendes. Em setembro de 2009, o processo se encontrava com vista para o Ministro Ricardo Lewandowski. Haviam votado favoravelmente ao caráter vinculante da decisão do STF, mesmo que em controle incidental de constitucionalidade, os Ministro Gilmar Mendes e Eros Grau. Divergiram, no particular, os Ministros Sepúlveda Pertence e Joaquim Barbosa.

${ }^{100}$ Med. Caut. no HC 95.009-4 - São Paulo, Rel. Min. Eros Grau. A decisão concessiva de ambos os habeas corpus foram do Presidente do Tribunal, Ministro Gilmar Mendes, em razão do recesso de julho.

${ }^{101}$ V. GINSBURG, Tom. Judicial review in new democracies: constitutional courts in Asian cases. New York: Cambridge University Press, 2003. Em resenha sobre diferentes livros versando o tema da judicialização, ROESLER, Shannon, em Permutations of judicial Power: the new constitutionalism and the expansion of judicial authority. Law and Social Inquiry, 2007, n. 32, p. 557, assim descreveu a posição de Ginsburg: "Os juízes são atores estratégicos que buscam aumentar seu poder em vez de interpretar e aplicar normas de acordo com a intenção ou os interesses originais dos agentes eleitos que as elaboraram. (...) Uma das premissas dessa abordagem é que os juízes vão buscar aumentar o poder de um tribunal, mesmo que divirjam entre si quanto ao direito substantivo" (tradução livre, texto ligeiramente editado).

${ }^{102}$ Nesse sentido, v. também Forum de Grupos de Pesquisa em direito Constitucional e Teoria do direito, Anais do I Forum de Grupos de Pesquisa em direito Constitucional e Teoria do direito. Rio de Janeiro: Faculdade Nacional de direito, 2009, p. 54: "A hipótese assumida na investigação reconhece, por parte dos integrantes do Supremo Tribunal Federal, sim um 'ativismo', mas de caráter jurisdicional. Isto é, um procedimento, construído a partir das mais relevantes decisões, objetivando, precipuamente, não a concretização de direitos, mas o alargamento de sua competência institucional”. Pesquisa "A judicialização da política e o ativismo judicial no Brasil”, conduzida por Alexandre Garrido da Silva et. al.

${ }^{103}$ STF DJ 17 out. 2008, MS no 26602/DF, Rel. Min. Eros Grau; DJ 19 dez. 2008, MS nº 26603/DF, Rel. Min. Celso de Mello; e DJ 3 out. 2008, MS nº 26604/DF, Rel. Min. Cármen Lúcia.

104 STF, DJ 18 dez.2009, ADC 12, Rel. Min. Carlos Britto; e DJ 24 out.2009. RE 579.951/RN, Rel. Min. Ricardo Lewandowski. 
interrupção da gestação em caso de feto anencefálico ${ }^{105}$ e da extensão do regime da união estável às uniões homoafetivas ${ }^{106}$ também envolvem uma atuação quase normativa do Supremo Tribunal Federal. Tudo sem mencionar a mudança jurisprudencial em tema de mandado de injunção ${ }^{107}$ e o progressivo questionamento que se vem fazendo, no âmbito da própria Corte, acerca da jurisprudência tradicional de que o STF somente possa funcionar como legislador negativo ${ }^{108}$.

Em 2009, o STF solucionou uma disputa constitucional - e de espaço político - entre a Ordem dos Advogados do Brasil (OAB) e o Superior Tribunal de Justiça (STJ), em favor da expansão do poder desse último. De fato, acórdão da $2^{\mathrm{a}}$. Turma do STF, por diferença de um voto, legitimou decisão do STJ de devolver lista sêxtupla enviada pela OAB, sem motivação objetiva, sob o fundamento de que nenhum dos nomes obteve quorum para figurar na lista tríplice a ser encaminhada ao Presidente da República ${ }^{109}$. A decisão, de certa forma, está em desacordo com precedente do próprio $\operatorname{STF}^{110}$ e esvazia a competência do órgão de representação dos advogados, cuja lista, doravante, estará sujeita a ingerência do STJ. A matéria não chegou ao Plenário do STF, onde o resultado, possivelmente, teria sido diverso.

\subsection{Relações com outros Poderes, órgãos e entidades estatais}

As manifestações processuais e extraprocessuais de outros Poderes, órgãos e entidades estatais são elementos relevantes do contexto institucional em que produzidas as decisões judiciais, especialmente do Supremo Tribunal Federal. Em tema de ações diretas de inconstitucionalidade, as ações movidas pelo Procurador-Geral da República têm o maior

\footnotetext{
${ }^{105}$ STF, ADPF no 54, Rel. Min. Marco Aurélio.

${ }^{106}$ STF, ADPF no 132, Rel. Min. Carlos Britto.

107 STF, DJ 6 nov. 2007, MI n 670, Rel. Min. Maurício Corrêa; DJ 31 out.2008, MI nº 708, Rel. Min. Gilmar Mendes; DJ 31 out.2008, MI n 712 , Rel. Min. Eros Grau.

${ }^{108}$ V. voto do Min. Gilmar Mendes em STF, ADIn no 3.510, Rel. Min. Carlos Britto: "Portanto, é possível antever que o Supremo Tribunal Federal acabe por se livrar do vetusto dogma do legislador negativo e se alie à mais progressiva linha jurisprudencial das decisões interpretativas com eficácia aditiva, já adotadas pelas principais Cortes Constitucionais européias. A assunção de uma atuação criativa pelo Tribunal poderá ser determinante para a solução de antigos problemas relacionados à inconstitucionalidade por omissão, que muitas vezes causa entraves para a efetivação de direitos e garantias fundamentais assegurados pelo texto constitucional".

109 Decisão do STJ: DJ 22 out. 2008, MS no 13532-DF, Rel. Min. Paulo Gallotti. Decisão do STF: DJ 4 dez. 2009, RMS 27920-DF, Rel. Min. Eros Grau.

${ }^{110}$ STF, DJ 19 dez.2006, MS 25624/DF, Rel. Min. Sepúlveda Pertence
} 
índice de acolhimento dentre todos os legitimados ${ }^{111}$. O parecer da Procuradoria-Geral da República - isto é, seu pronunciamento nos casos em que não é parte - é visto como expressão do interesse público primário que deve ser preservado na questão. A despeito da ausência de pesquisas empíricas, é possível intuir que um percentual muito significativo das decisões do STF acompanha a manifestação do Ministério Público Federal ${ }^{112}$. Já a atuação da Advocacia-Geral da União expressará o interesse ou o ponto de vista do Poder Executivo, especialmente do Presidente da República. Em questões que envolvem a Fazenda Pública, estudos empíricos certamente demonstrariam uma atuação favorável ao erário, revelada emblematicamente em questões de vulto, como as relativas ao FGTS, à Cofins ou ao IPI alíquota zero, por exemplo. Em todas elas, a Corte alterou ou a sua própria jurisprudência ou a do Superior Tribunal de Justiça, dando ganho de causa à União ${ }^{113}$. A cultura política dominante ainda considera aceitável que Ministros de Estado visitem pessoalmente os Ministros do Supremo Tribunal Federal, por vezes após iniciados os julgamentos, para pedirem decisões favoráveis ao ponto de vista em que têm interesse ${ }^{114}$.

Também o Congresso Nacional apresenta defesa em processos nos quais seja parte e, especialmente, em ações diretas contra leis federais. Sendo a ação direta de inconstitucionalidade contra lei estadual, também participam do processo a Assembleia Legislativa e o Governador do Estado. Note-se que o peso político do Estado pode fazer diferença em relação à deferência para com a legislação estadual. Por exemplo: após inúmeras decisões considerando inconstitucionais leis estaduais que proibiam o uso do amianto, o STF

\footnotetext{
111 V. VIANNA, Luiz Werneck; BURGOS, Marcelo Baumann; SALLES, Paula Martins. Dezessete anos de judicialização da política. Tempo Social, São Paulo, v. 19, n.2, p. 43, 48 e 79, de onde se colheram os dados a seguir. Entre 1988 e 2005, foram ajuizadas 1.713 Adins. Destas, 810 foram ajuizadas pelo PGR (22,2\% do total). De acordo com a pesquisa, o PGR "teve nada menos que 68,5\% das liminares de Adins julgadas deferidas ou parcialmente deferidas". No mesmo sentido: CARVALHO, Ernani. Judicialização da política no Brasil: controlo de constitucionalidade e racionalidade política. Análise Social, Lisboa, 2009, v. 44, n.191, p. 327.

${ }^{112}$ Recente pesquisa empreendida pelo autor revelou que em cem pedidos de extradição, apenas três resultaram em decisões que não acompanharam a manifestação do Ministério Público.

${ }^{113}$ No caso do FGTS, deixou de considerar o tema do direito adquirido como infraconstitucional. No da Cofins, mudou a orientação sumulada pelo STJ, mesmo depois de haver recusado conhecimento a diversos recursos extraordinários na matéria, e sequer modulou os efeitos, como seria próprio em razão da alteração da jurisprudência. No IPI alíquota zero, considerou que uma decisão do Plenário por 9 a 1, decisão de uma das turmas e mais de 5 dezenas de decisões monocráticas não firmavam jurisprudência. Em seguida, mudou a orientação, igualmente sem modular efeitos.

${ }^{114}$ V. BRÍGIDO, Carolina; TAVARES, Mônica; RODRIGUES, Eduardo. Decisão do STF mantém monopólio dos Correios. Blog do Noblat, 6 ago. 2009: "O ministro das Comunicações, Helio Costa, empenhou-se na defesa dos interesses econômicos da ECT. Na terça-feira, após classificar de desastre a eventual abertura do mercado de cartas comerciais à iniciativa privada, ele foi ao STF para conversar a portas fechadas com Ayres Brito e Gilmar Mendes, presidente da Corte". Disponível em: http://oglobo.globo.com/pais/noblat/posts/2009/08/06/decisao-dostf-mantem-monopolio-dos-correios-211690.asp. Acesso em: 16.mai.2011.
} 
deixou de conceder medida cautelar para suspender lei do Estado de São Paulo que dispunha no mesmo sentido, revisitando tema que se encontrava já pacificado na Corte ${ }^{115}$.

\section{Perspectiva de cumprimento efetivo da decisão}

Tribunais, como os titulares de poder em geral, não gostam de correr o risco de que suas decisões não sejam efetivamente cumpridas. E, portanto, esta é uma avaliação ordinariamente feita por órgãos judiciais, ainda que não seja explicitada. Tribunais Congresso ou mesmo da aceitação social para que suas deliberações sejam cumpridas. Há exemplos, em diferentes partes do mundo, de decisões que não se tornaram efetivas. Na Itália, aliás, o primeiro Presidente do Tribunal Constitucional renunciou precisamente por essa razão ${ }^{116}$. Na Alemanha, a decisão no célebre caso do crucifixo foi generalizadamente desrespeitada ${ }^{117}$. Nos Estados Unidos, a dessegregação imposta por Brown v. Board of Education, em decisão de 1954, levou mais de uma década para começar a ser efetivamente cumprida ${ }^{118}$. A decisão no caso Chada foi ignorada pelo Congresso ${ }^{119}$. No Brasil, há precedentes em que o STF fixou prazo para a atuação do legislador, sem que tivesse sido obedecido ${ }^{120}$. Em tema de

115 STF, Inf. STF $n^{\circ} 477$ e 509, ADI no 3937 MC/SP, Rel. Min. Marco Aurélio. O relator votou na linha do entendimento tradicional, expresso em decisões como a das ADIs nºs. 2656/SP e 2396/MS. Mas o Min. Eros Grau deu início à dissidência, suscitando a inconstitucionalidade da própria lei federal que cuida da matéria.

116 Criada pela Constituição de 1948, a instalação efetiva da Corte Constitucional somente se deu oito anos depois, em 1956. Pouco tempo após, seu Presidente, Enrico de Nicola, renunciou ao cargo, indignado com a recalcitrância do governo democrata-cristão em dar cumprimento às decisões do tribunal. V. ITALY: Effective Resignation. Revista Time, $\quad 1^{\circ}$.out.1956. Disponível em: http://www.time.com/time/magazine/article/0,9171,862380,00.html. Acesso em: 23.jan.2010. V. tb. VANBERG, Georg. The politics of constitutional review in Germany. Cambridge University Press, Cambridge, 2005, p. 7.

${ }^{117}$ A decisão declarou inconstitucional uma lei da Bavária que previa a exibição de crucifixos nas salas de aula das escolas públicas de ensino fundamental. V. BVerfGE 93, I. Sob protestos e manifestações que mobilizaram milhares de pessoas, os crucifixos terminaram não sendo efetivamente retirados. V. VANBERG, Georg. The politics of constitutional review in Germany. Cambridge University Press, Cambridge, 2005, p. 2-4.

118 V. COTTROL, Robert J.; DIAMOND, Raymond T.; e WARE, Leland B.. Brown v. Board of Education: case, culture, and the constitution. Lawrence: University Press of Kansas, 2003, p. 183.

${ }^{119}$ INS v. Chadda, 462 U.S. 919, 1983. Nessa decisão, a Suprema Corte considerou inconstitucional o chamado legislative veto, procedimento pelo qual uma das Casas do Congresso poderia suspender decisões de agências reguladoras que estivessem atuando por delegação legislativa. A Corte entendeu que a providência somente poderia ser tomada mediante lei, que inclui a manifestação das duas Casas e a possibilidade de veto pelo Presidente. Não obstante isso, inúmeras leis foram aprovadas, prevendo o veto legislativo por apenas uma das Casas do Congresso. V. VANBERG, Georg. The politics of constitutional review in Germany. Cambridge University Press, Cambridge, 2005, p. 5 e s.

${ }^{120}$ V. STF, DJ 3 ago. 2007, Adin 2240, Rel. Min. Eros Grau, No julgamento do Mandado de Injunção $n^{\circ} 725$, o STF determinara que o Congresso Nacional, no prazo de 18 meses, editasse a lei complementar federal referida no $\S 4^{\circ}$ do art. 18 da Constituição, o que não aconteceu. 
intervenção federal, a despeito do manifesto descumprimento por Estados da Federação do dever constitucional de pagar precatórios, a Corte igualmente optou por linha jurisprudencial que não desmoralizasse suas decisões, diante das dificuldades financeiras dos entes estatais ${ }^{121}$. Outro exemplo emblemático, nesse domínio, foi a decisão proferida em 1955, quando da tentativa do Vice-Presidente Café Filho de retornar à presidência ${ }^{122}$.

\section{Circunstâncias internas dos órgãos colegiados}

Inúmeros fatores extrajurídicos influenciam as decisões de um órgão colegiado ${ }^{123}$. No caso do Supremo Tribunal Federal, em particular, a primeira característica distintiva relevante é que o tribunal delibera em sessão pública. Na maior parte dos países, sem embargo da existência de uma audiência pública, de um hearing, com a intervenção dos advogados, o processo de discussão e decisão é interno, em conferência reservada, na qual participam apenas os ministros ou juízes. A deliberação pública é uma singularidade brasileira. A transmissão ao vivo dos julgamentos, por uma televisão oficial, constitui traço distintivo ainda mais original, talvez sem outro precedente pelo mundo afora ${ }^{124}$. Em parte como consequência desse modelo de votação pública, o sistema brasileiro segue um padrão agregativo e não propriamente deliberativo. Vale dizer: a decisão é produto da soma de votos individuais e não

${ }^{121}$ O STF adotou a orientação de que somente autorizaria a intervenção federal o descumprimento doloso do dever de pagar precatórios. A omissão na inclusão das verbas correspondentes em orçamento e a falta de recursos são, assim, elementos suficientes para afastar a intervenção. Nesse sentido, v., por todos, STF, DJ 25 abr. 2008, IF $5050 \mathrm{AgR/SP}, \mathrm{Rel}^{\mathrm{a}}$. Min ${ }^{\mathrm{a}}$. Ellen Gracie.

${ }^{122}$ Vice-presidente no segundo governo de Getúlio Vargas, Café Filho assumiu a presidência após o suicídio de Vargas, em 1954. Dela afastou-se, por motivo de saúde, tendo sido substituído por Carlos Luz. Após a eleição de Juscelino, em 1955, o Marechal Henrique Lott liderou um "contragolpe preventivo" para assegurar a posse do presidente eleito, destituindo Carlos Luz. Quando Café Filho, já recuperado, tenta voltar à presidência por via de ação impetrada no STF, a Corte adia o julgamento até o fim do Estado de sítio, o que somente se daria por ocasião da posse de Juscelino, quando o mandado de segurança já estaria prejudicado. Interessante registro histórico é o do voto vencido do Ministro Nelson Hungria, que lavrou: "Contra uma insurreição pelas armas, coroada de êxito, somente valerá uma contra-insurreição com maior força. E esta, positivamente, não pode ser feita pelo Supremo Tribunal, posto que este não iria cometer a ingenuidade de, numa inócua declaração de princípios, expedir mandado para cessar a insurreição. (...) O impedimento do impetrante para assumir a Presidência da República, antes de ser declaração do Congresso, é imposição das forças insurreicionais do Exército, contra a qual não há remédio na farmacologia jurídica. Não conheço do pedido de segurança". V. BARROSO, Luís Roberto. O direito constitucional e a efetividade de suas normas. 9. ed. Rio de Janeiro: Renovar, 2009, p. 29-30.

123 Sobre o tema, v. BARBOSA MOREIRA, José Carlos. "Notas sobre alguns fatores extrajurídicos no julgamento colegiado". Caderno de Doutrina e Jurisprudência da Ematra XV, v. 1, n. 3, 2005, p. 79 e s.

${ }^{124}$ A despeito de críticas e de um ou outro inconveniente que se pode apontar, a transmissão ao vivo deu visibilidade, transparência e legitimidade democrática à jurisdição constitucional exercida pelo Supremo Tribunal Federal no Brasil. 
da construção argumentativa de pronunciamentos consensuais ou intermediários ${ }^{125}$. Isso não significa que não possam ocorrer mudanças de opinião durante os debates. Mas o modelo não é concebido como uma troca de impressões previamente à definição de uma posição final.

Nada obstante isso, um colegiado nunca será a mera soma de vontades individuais, mesmo em um sistema como o brasileiro. Não é incomum um Ministro curvar-se à posição da maioria, ao ver seu ponto de vista derrotado. Por vezes, os julgadores poderão procurar, mediante concessões em relação à própria convicção, produzir um resultado de consenso ${ }^{126}$. Alinhamentos internos, em função da liderança intelectual ou pessoal de um Ministro, podem afetar posições. Por vezes, até mesmo um desentendimento pessoal poderá produzir impacto sobre a votação. Ainda quando possa ocorrer em qualquer tribunal do mundo, seria menos aceitável, eticamente, a troca de apoios em casos diversos: um Ministro acompanhando o outro em determinada votação, em troca de reciprocidade - em típica apropriação da linguagem político-partidária ${ }^{127}$. Também podem influenciar decisivamente o resultado de um julgamento o relator sorteado, a ordem de votação efetivamente seguida ou mesmo um pedido de vista. Por igual, o método de seleção de casos a serem conhecidos e a elaboração da própria pauta de julgamentos envolve escolhas políticas acerca da agenda da corte a cada tempo $^{128}$.

\footnotetext{
${ }^{125} \mathrm{Na}$ Suprema Corte americana, coube a John Marshall a transformação do modelo agregativo ou seriatim para o modelo de discussão prévia, com vistas à produção de consenso. V. NELSON, William E.. The province of the Judiciary. John Marshall Law Review, 2004, n. 37, p. 345. V. tb. FRIEDMAN, Barry. The politics of judicial review. Texas Law Review, Austin, 2005, v. 84, n. 2, p. 284: "No modelo agregativo, as decisões colegiadas simplesmente cumulam as visões dos membros do tribunal. No modelo deliberativo, os julgadores devem interagir de modo a que cada um considere os pontos de vista do outro, produzindo-se, dessa forma, melhores decisões".

${ }^{126}$ Com efeito, pesquisa realizada nos EUA concluiu que juízes federais atuando em colegiados de três membros são afetados pela forma como votam os colegas: se um juiz nomeado por Presidente republicano atua com dois nomeados por Presidente democrata, seus votos mostram padrões liberais, enquanto um juiz nomeado por um democrata vota em linha mais conservadora quando atua com dois nomeados por Presidente republicano. Em qualquer dos casos, os padrões tornam-se mais moderados se há, no órgão, juízes nomeados por Presidentes de partidos diversos. O resultado da pesquisa é relatado por THALER, Richard H. e SUNSTEIN, Cass R.. Nudge: improving decisions about health, wealth, and happiness. New Haven: Yale University Press, 2009, p. 55.

127 Sobre comportamentos estratégicos no âmbito de órgãos colegiados, v. Evan H. Caminker, Sincere and strategic: voting norms on multimbember courts, Michigan Law Review 97:2297, 1999; Robert Post, The Supreme Court opinion as institutional practice: dissent, legal scholarship and decisiomaking in the COURT, Taft. Minnesota Law Review, Minessota, 2001, v. 85, p. 1267; e V. FRIEDMAN, Barry. The politics of judicial review. Texas Law Review, Austin, 2005, v. 84, n. 2, p. 287.

128 A repercussão geral, introduzida pela Emenda Constitucional $n^{\circ} 45$, de 2004, e regulamentada pela Lei $n^{\circ}$ 11.418, de 19.12.2006, produziu significativa redução do volume de processos julgados pelo STF. O número, todavia, ainda é muito superior ao máximo possível tolerável. A pauta das sessões plenárias é elaborada pelo presidente da Corte, que seleciona, com razoável grau de discrição, as prioridades. A própria ordem de inserção de um processo na pauta pode ter repercussão sobre o resultado do julgamento. BARBOSA MOREIRA, José Carlos. Notas sobre alguns fatores extrajurídicos no julgamento colegiado. Caderno de Doutrina $e$ Jurisprudência da Ematra XV, v. 1, n. 3, 2005, p. 82.
} 


\section{A opinião pública}

O poder de juízes e tribunais, como todo poder político em um Estado democrático, é representativo. Vale dizer: é exercido em nome do povo e deve contas à sociedade. Embora tal assertiva seja razoavelmente óbvia, do ponto de vista da teoria democrática, a verdade é que a percepção concreta desse fenômeno é relativamente recente. $\mathrm{O}$ distanciamento em relação ao cidadão comum, à opinião pública e aos meios de comunicação fazia parte da autocompreensão do Judiciário e era tido como virtude ${ }^{129}$. O quadro, hoje, é totalmente diverso $^{130}$. De fato, a legitimidade democrática do Judiciário, sobretudo quando interpreta a Constituição, está associada à sua capacidade de corresponder ao sentimento social. Cortes constitucionais, como os tribunais em geral, não podem prescindir do respeito, da adesão e da aceitação da sociedade. A autoridade para fazer valer a Constituição, como qualquer autoridade que não repouse na força, depende da confiança dos cidadãos. Se os tribunais interpretarem a Constituição em termos que divirjam significativamente do sentimento social, a sociedade encontrará mecanismos de transmitir suas objeções e, no limite, resistirá ao cumprimento da decisão ${ }^{131}$.

A relação entre órgãos judiciais e a opinião pública envolve complexidades e sutilezas. De um lado, a atuação dos tribunais, em geral - e no controle de constitucionalidade das leis, em particular -, é reconhecida, de longa data, como um mecanismo relevante de contenção das paixões passageiras da vontade popular. De outra parte, a ingerência do Judiciário, em linha oposta à das maiorias políticas, enfrenta, desde sempre, questionamentos quanto à sua legitimidade democrática. Nesse ambiente, é possível estabelecer uma correlação entre Judiciário e opinião pública e afirmar que, quando haja desencontro de posições, a tendência é no sentido de o Judiciário se alinhar ao sentimento social ${ }^{132}$. Três exemplos de decisões do

\footnotetext{
129 Sobre este ponto, v. BARROSO, Luís Roberto. "A segurança jurídica na era da velocidade e do pragmatismo". In: Temas de direito constitucional, tomo I. 2. ed. Rio de Janeiro: Renovar, 2002, p. 69 e s.

${ }^{130}$ Sobre o modo como os juízes veem a si mesmos e à sua função, v. pesquisa realizada em 2005 "Magistrados brasileiros: caracterização e opiniões", patrocinada pela Associação dos Magistrados Brasileiros, sob a coordenação de Maria $\quad$ Tereza $\quad$ Sadek. Disponível http://www.amb.com.br/portal/docs/pesquisa/PesquisaAMB2005.pdf. Sobre a mudança de perfil da magistratura, pela incorporação das mulheres e de magistrados cuja origem está em família mais humildes, v. entrevista dada pela pesquisadora à revista eletrônica Consultor Jurídico, 8 fev. 2009.

${ }^{131}$ POST, Robert; SIEGEL, Reva. Roe rage: democratic constitutionalism and backlash. Harvard Civil RigtsCivil Liberties Law Review, Cambridge, 2007, n. 42, p. 373.

${ }^{132}$ FRIEDMAN, Barry. The politics of judicial review. Texas Law Review, Austin, 2005, v. 84, n. 2, p. 321-2.
} 
Supremo Tribunal Federal, no Brasil, que representaram revisão de entendimentos anteriores que não correspondiam às demandas sociais: a limitação das hipóteses de foro por prerrogativa de função (cancelamento da Súmula no 394 ); a proibição do nepotismo, conduta que por longo tempo foi social e juridicamente aceita; e a imposição de fidelidade partidária, penalizando o "troca-troca" de partidos após as eleições ${ }^{133}$. Nos Estados Unidos, a Suprema Corte, na década de 30, após se opor tenazmente às políticas sociais do New Deal, terminou por se alinhar com as iniciativas de Roosevelt, que tinham amplo apoio popular. Mais recentemente, passou-se o mesmo em relação à descriminalização das relações homossexuais ${ }^{134}$.

Todavia, existe nesse domínio uma fina sutileza. Embora deva ser transparente e prestar contas à sociedade, o Judiciário não pode ser escravo da opinião pública. Muitas vezes, a decisão correta e justa não é a mais popular. Nessas horas, juízes e tribunais não devem hesitar em desempenhar um papel contramajoritário. O populismo judicial é tão pernicioso à democracia como o populismo em geral. Em suma: no constitucionalismo democrático, o exercício do poder envolve a interação entre as cortes judiciais e o sentimento social, manifestado por via da opinião pública ou das instâncias representativas. A participação e o engajamento popular influenciam e legitimam as decisões judiciais, e é bom que seja $\operatorname{assim}^{135}$. Dentro de limites, naturalmente. O mérito de uma decisão judicial não deve ser aferido em pesquisa de opinião pública. Mas isso não diminui a importância de o Judiciário, no conjunto de sua atuação, ser compreendido, respeitado e acatado pela população. A opinião pública é um fator extrajurídico relevante no processo de tomada de

\footnotetext{
${ }^{133}$ Exemplo inverso, em que o STF não seguiu a opinião pública dominante, envolveu a questão da elegibilidade de candidatos que tivessem "ficha-suja", isto é, tivessem sofrido condenações judiciais, ainda que não transitadas em julgado. A Corte entendeu que só a lei complementar, prevista no $§ 9^{\circ}$ do art. 14 da Constituição, poderia instituir outros casos de inelegibilidade. Inf. STF $n^{o}$ 514, ADPF 144, Rel. Min. Celso de Mello.

${ }^{134}$ Em Bowers v. Hardwick, julgado em 1986, a Suprema Corte considerou constitucional lei estadual que criminalizava a sodomia. Em 2003, ao julgar Lawrence v. Texas, considerou inconstitucional tal criminalização. A Ministra Sandra O'Connor, que votou com a maioria nos dois casos - isto é, mudou de opinião de um caso para o outro -, observou em seu livro The majesty of the law: reflections of a Supreme Court Justice. New York: Random House, 2003, p. 166: "Mudanças reais, quando chegam, derivam principalmente de mudanças de atitude na população em geral. É rara a vitória jurídica - no tribunal ou no legislativo - que não seja a conseqüência de um novo consenso social. Tribunais, em particular, são notadamente instituições reativas".

${ }^{135}$ V., a propósito, uma vez mais, o depoimento de O’CONNOR, Sandra. Public trust as a dimension of equal justice: some suggestions to increase public trust. The Supreme Court Review, 1999, n. 36, p. 13. "Nós não possuímos forças armadas para dar cumprimento a nossas decisões, nós dependemos da confiança do público na correção das nossas decisões. Por essa razão, devemos estar atentos à opinião e à atitude públicas em relação ao nosso sistema de justiça, e é por isso que precisamos tentar manter e construir esta confiança".
} 
decisões por juízes e tribunais ${ }^{136}$. Mas não é o único e, mais que isso, nem sempre é singela a tarefa de captá-la com fidelidade ${ }^{137}$.

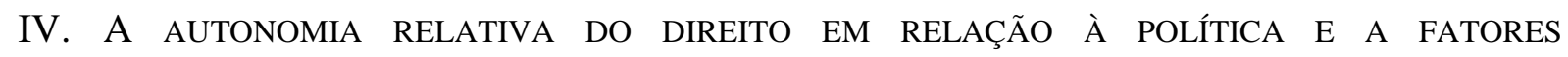
EXTRAJUDICIAIS

$\mathrm{Na}$ literatura jurídica norte-americana, os autores costumam identificar modelos diversos de comportamento judicial, dentre os quais se destacam o legalista, o ideológico e o estratégico $^{138}$. O modelo legalista corresponde à concepção mais tradicional, próxima ao formalismo jurídico, crente na objetividade do direito e na neutralidade do intérprete. $\mathrm{O}$ modelo ideológico coloca ênfase nas preferências políticas pessoais do juiz como fator determinante das decisões judiciais. O modelo estratégico, por sua vez, leva em conta pretensões de juízes e tribunais de conservação e expansão de seu poder, conjugada com a preocupação de ver suas decisões cumpridas e, no limite, assegurar a própria sobrevivência. O presente trabalho desenvolveu-se sobre a crença de que nenhum dos três modelos prevalece em sua pureza: a vida real é feita da combinação dos três. Sem embargo das influências políticas e das opções estratégicas, o direito conservará sempre uma autonomia parcial ${ }^{139}$.

\footnotetext{
${ }^{136} \mathrm{Na}$ sustentação oral, no julgamento da ADI n $\mathrm{n}^{\mathrm{o}}$ 3.510-DF, este foi um dos pontos destacados: o fato de que as entidades da sociedade civil, maciçamente, e a opinião pública, em percentuais bastante elevados, apoiavam a legitimidade das pesquisas com células-tronco embrionárias. V. O vídeo está disponível em: http://www.lrbarroso.com.br/pt/videos/celula_tronco_1.html.

${ }^{137}$ A sintonia com a opinião pública envolve diversas nuances. Por vezes, grupos de pressão bem situados são capazes de induzir ou falsear a real vontade popular. De parte isso, a opinião pública, manipulada ou não, sofre variações, por vezes abruptas, em curto espaço de tempo. Será preciso, assim, distinguir, com as dificuldades previsíveis, entre clamor público, paixões do momento e opinião sedimentada. Ted Roosevelt, antigo presidente norte-americano, referiu-se à distinção entre "vontade popular permanente" e "opinião pública do momento. Sobre esse último ponto, v. FRIEDMAN, Barry. The will of the people: how public opinion has influenced the Supreme Court and shaped the meaning of the Constitution. New York: Farrar, Straus and Giroux, 2009, p. 382.

${ }^{138}$ V. SEGAL, Jeffrey A.; SPAETH, Harold J.. The Supreme Court and the attitudinal model revisited. New York: Cambridge University Press, 2002; EPSTEIN, Lee; KNIGHT, Jack. The choices justices make. Washington, DC: CQ Press, 1998; POSNER, Richard. How judges think?. Cambridge: Harvard University Press, 2008, p. 19-56, identifica "nove teorias de comportamento judicial": ideological, estratégica, organizacional, econômica, psicológica, sociológica, pragmática, fenomenológica e legalista . V. tb. SUNSTEIN, Cass; SCHKADE, David; ELLMAN, Lisa M.; SAWICKI, Andres. Are judges political? An empirical analysis of the Federal Judiciary. Washington, DC: Brookings Institution, 2006; e POSNER, Richard. How judges think. Cambridge: Harvard University Press, 2008.

${ }^{139}$ Este é, também, o ponto de vista de Michael Dorf, em No litmus test: Law versus politics in the twentieth century. Lanham: Rowman \& Littlefield, 2006. O autor defende uma posição intermediária entre os extremos representados pelo realismo e pelo formalismo. Em suas palavras: "Os realistas prestam um serviço importante ao corrigirem a visão exageradamente mecânica que os formalistas têm do direito. Mas vão longe demais ao sugerirem que não há nada de especificamente jurídico na metodologia de decisão empregada pelos tribunais e outros atores jurídicos".
} 
Ainda quando não possa oferecer todas as soluções pré-prontas em seus enunciados normativos, conceitos e precedentes, o direito limita as possibilidades legítimas de solução. De fato, deverão elas caber nas alternativas de sentido e de propósitos dos textos, assim como harmonizar-se com o sistema jurídico como um todo. De parte isso, os argumentos utilizáveis em um processo judicial na construção de qualquer decisão precisam ser assimiláveis pelo direito, não somente por serem de razão pública, mas por seguirem a lógica jurídica, e não a de qualquer outro domínio ${ }^{140}$. Ademais, a racionalidade e a razoabilidade de qualquer decisão estará sujeita, no mínimo, à revisão por um segundo grau de jurisdição, assim como ao controle social, que hoje é feito em sítios jurídicos na internet, em fóruns de debates e, crescentemente, na imprensa geral. Vale dizer: a atuação judicial é limitada pelas possibilidades de solução oferecidas pelo ordenamento, pelo tipo de argumentação jurídica utilizável e pelo controle de razoabilidade e de racionalidade que restringem as influências extrajudiciais de natureza ideológica ou estratégica. Mas não as inibem inteiramente. Reconhecer isso não diminui o direito, mas antes permite que ele se relacione com a política de maneira transparente, e não escamoteada.

\section{Conclusão}

\section{ENTRE A RAZÃO E A VONTADE}

Examinando cada uma das partes em que se dividiu o presente trabalho, é possível enunciar, em proposições objetivas, três ideias básicas:

1. Um dos traços mais marcantes do constitucionalismo contemporâneo é a ascensão institucional do Poder Judiciário. Tal fenômeno se manifesta na amplitude da jurisdição constitucional, na judicialização de questões sociais, morais e políticas, bem como em algum grau de ativismo judicial. Nada obstante isso, deve-se cuidar para que juízes e tribunais não se transformem em uma instância hegemônica, comprometendo a legitimidade democrática de sua atuação, exorbitando de suas capacidades institucionais e limitando impropriamente o debate público. Quando não estejam em jogo os direitos fundamentais ou a preservação dos

\footnotetext{
${ }^{140}$ A lógica jurídica, como intuitivo, é diferente da econômica, da histórica ou da psicanalítica. Por exemplo: um juiz não poderá se recusar a aplicar uma regra que exacerbe a proteção do inquilino em um contrato de aluguel, sob o fundamento de que a teoria econômica já provou que o protecionismo produz efeito negativo sobre os interesses dos inquilinos em geral, por diminuir a oferta de imóveis e aumentar o preço da locação. Cabe-lhe aplicar a norma mesmo que discorde da lógica econômica subjacente a ela.
} 
procedimentos democráticos, juízes e tribunais devem acatar as escolhas legítimas feitas pelo legislador, assim como ser deferentes com o exercício razoável de discricionariedade pelo administrador, abstendo-se de sobrepor a eles sua própria valoração política. Ademais, a jurisdição constitucional não deve suprimir nem oprimir a voz das ruas, o movimento social e os canais de expressão da sociedade. Nunca é demais lembrar que o poder emana do povo, não dos juízes.

2. Na concepção tradicional e idealizada, direito e política integram mundos apartados, que não devem se comunicar. Para realizar tal propósito, o Judiciário é dotado de garantias que visam a assegurar sua independência e os órgãos judiciais são vinculados ao direito posto. Vale dizer: limitar-se-iam a aplicar a Constituição e as leis, produtos da vontade do constituinte e do legislador, sem exercer vontade política própria nem atividade criativa. Essa pretensão de autonomia absoluta do direito em relação à política é impossível de se realizar. As soluções para os problemas nem sempre são encontradas prontas no ordenamento jurídico, precisando ser construídas argumentativamente por juízes e tribunais. Nesses casos - ao menos neles -, a experiência demonstra que os valores pessoais e a ideologia do intérprete desempenham, tenha ele consciência ou não, papel decisivo nas conclusões a que chega.

3. Embora não possa oferecer soluções pré-prontas em muitas situações, o direito limita as possibilidades legítimas de solução que podem ser construídas pelos intérpretes judiciais. Com isso, contém-se parcialmente o exercício de escolhas voluntaristas e arbitrárias. De parte isso, inúmeros outros fatores influenciam a atuação de juízes e tribunais, como a interação com outros atores políticos e institucionais, preocupações com o cumprimento das decisões judiciais, circunstâncias internas dos órgãos colegiados e a opinião pública, dentre outros. Em suma: o direito pode e deve ter uma vigorosa pretensão de autonomia em relação à política. Isso é essencial para a subsistência do conceito de Estado de direito e para a confiança da sociedade nas instituições judiciais. Essa autonomia, todavia, será sempre relativa. Reconhecer este fato não envolve qualquer capitulação, mas antes dá transparência a uma relação complexa, na qual não pode haver hegemonia nem de um nem de outro. A razão pública e a vontade popular - o direito e a política, se possível com maiúscula - são os dois pólos do eixo em torno do qual o constitucionalismo democrático executa seu movimento de rotação. Dependendo do ponto de observação de cada um, às vezes será noite, às vezes será dia. 
AGUIAR, Thais Florencio de. A judicialização da política ou o rearranjo da democracia liberal, Ponto e Vírgula, n. 2, São Paulo, $2^{\circ}$ sem. 2007.

ARANTES, Rogério Bastos. Constitutionalism, the expansion of justice and the judicialization of politics in Brazil. In: SIEDER, Rachel; SCHJOLDEN, Line e ANGELL, Alan. The judicialization of politics in Latin America. Nova York: Palgrave MacMillan, 2005.

Judiciário: entre a justiça e a política. Disponível em: $<\mathrm{http}$ //academico.direito-rio.fgv.br/ccmw/images/9/9d/Arantes.pdf >.

ARGUELLES, Diego Werneck. Deuses pragmáticos, mortais formalistas: a justificação consequencialista das decisões judiciais. Dissertação (Mestrado) - Programa de PósGraduação em Direito Público da Universidade do Estado do Rio de Janeiro, Rio de Janeiro, 2006. Mimeografado.

; LEAL, Fernando. Pragmatismo como [meta] teoria normativa da decisão judicial: caracterização, estratégia e implicações. In: SARMENTO, Daniel (Coord.). Filosofia e teoria constitucional contemporânea. Rio de Janeiro: Lumen Juris, 2009.

ARISTÓTELES. Ética a Nicômaco. 2. ed. São Paulo: Edipro, 2007.

BARAK, Aharon. The judge in a democracy. Princeton: Princeton University Press, 2006.

BARCELLOS, Ana Paula de. Constitucionalização das políticas públicas em matéria de direitos fundamentais: o controle político-social e o controle jurídico no espaço democrático, Revista de Direito do Estado, n. 3, Rio de Janeiro, jul./set. 2006.

BARNETT, Randy E. Constitututional clichés. Capital University Law Review, n. 36, Columbus, 2007.

BARROSO, Luís Roberto. A americanização do direito constitucional e seus paradoxos. In: Temas de direito constitucional, t. IV. Rio de Janeiro: Renovar, 2009.

A segurança jurídica na era da velocidade e do pragmatismo. In: Temas de direito constitucional, t. I. 2. ed. Rio de Janeiro: Renovar, 2002.

Constitucionalidade e legitimidade da criação do Conselho Nacional de Justiça. Interesse Público, n. 30, Porto Alegre, mar./abr. 2005.

Curso de direito constitucional contemporâneo. Rio de Janeiro: Saraiva, 2009.

- Da falta de efetividade à constitucionalização excessiva: direito à saúde, fornecimento gratuito de medicamentos e parâmetros para a atuação judicial. In: Temas de direito constitucional, t. IV. Rio de Janeiro: Renovar, 2009.

Judicialização, ativismo judicial e legitimidade democrática. Revista de Direito do Estado, Rio de Janeiro, n. 13, jan./mar. 2009.

O direito constitucional e a efetividade de suas normas. 9. ed. Rio de Janeiro: Renovar, 2009.

Sustentação oral no julgamento da ADI $\mathrm{n}^{\circ}$ 3.510/DF. Disponível em: <http://www.lrbarroso.com.br/pt/videos/celula_tronco_1.html>.

BICKEL, Alexander. The least dangerous branch. 2. ed. New Haven: Yale University Press, 1986. 
BORK, Robert H. Coercing virtue: the worldwide rule of judges. Washington: American Enterprise Institute Press, 2003.

BRASIL. Supremo Tribunal Federal. Audiência pública - Saúde. Disponível em: $<$ http://www.stf.jus.br/portal/cms/verTexto.asp?servico=processoAudienciaPublicaSaud e>.

CAMINKER, Evan H. Sincere and strategic: voting norms on multimember courts. Michigan Law Review, n. 97, Ann Arbor, 1999.

CÁRCOVA, Carlos María. Teorías jurídicas alternativas: escritos sobre derecho y política. Buenos Aires: Centro Editor de América Latina, 1993.

CARVALHO, Ernani. Em busca da judicialização da política no Brasil: apontamentos para uma nova abordagem. Revista de Sociologia Política, n. 23, Curitiba, nov. 2004.

Judicialização da política no Brasil: controle de constitucionalidade e racionalidade política. Análise Social, n. 44, Lisboa, 2º trim. 2009.

CHEMERINSKY, Erwin. Perspective on Justice: and federal law got narrower, narrower. Los Angeles Times. 18 mai. 2000.

CITTADINO, Giselle. Judicialização da política, constitucionalismo democrático e separação de Poderes. In: VIANNA, Luiz Werneck (Org.). A democracia e os três Poderes no Brasil. Belo Horizonte: UFMG, 2002.

CLÈVE, Clèmerson Merlin. A atividade legislativa do Poder Executivo. 2. ed. São Paulo: Revista dos Tribunais, 2000.

COELHO, Luiz Fernando. Teoria crítica do direito. 2. ed. Porto Alegre: Sérgio Antônio Fabris Editor, 1991.

COLEMAN, Jules. The practice of principle: in defence of a pragmatic approach to legal theory. Oxford: Oxford University Press, 2001.

COTTROL, Robert J.; DIAMOND, Raymond T. e WARE, Leland B. Brown v. Board of Education: case, culture, and the constitution. Lawrence: University Press of Kansas, 2003.

CROSS, Frank B. e LINDQUIST, Stefanie A. The scientific study of judicial activism. Minnesota Law Review, n. 91, Minneapolis, fev. 2007.

DORF, Michael. No litmus test: Law versus politics in the twentieth century. Lanham: Rowman \& Littlefield Publishers, 2006.

DWORKIN, Ronald. A matter of principle. Cambridge: Harvard University Press, 1985. . Looking for Cass Sunstein. The New York Review of Books, n. 56, Nova York, 30 abr. 2009. Também disponível em: 〈http://www.nybooks.com/articles/22636> .

O império do direito. São Paulo: Martins Fontes, 1999.

Taking rights seriously. 16. ed. Cambridge: Harvard University Press, 1997.

EPSTEIN, Lee e KNIGHT, Jack. The choices justices make. Washington: CQ Press, 1998.

FERRAJOLI, Luigi. Pasado y futuro del Estado de derecho. In: CARBONELL, Miguel (Org.). Neoconstitucionalismo(s). 2. ed. Madri: Trotta, 2003.

FISHER III, William W.; HORWITZ, Morton J. e REED, Thomas A. (Eds.). American legal realism. Nova York: Oxford University Press, 1993. 
FRANK, Jerome. What courts do in fact. Illinois Law Review, n. 26, Champaing, 1932.

FRIEDMAN, Barry. The politics of judicial review. Texas Law Review, n. 84, Austin, nov. 2005.

The will of the people: how public opinion has influenced the Supreme Court and shaped the meaning of the Constitution. Nova York: Farrar, Straus and Giroux, 2009.

GARCIA NETO, Paulo Macedo. A influência do realismo jurídico americano no direito constitucional brasileiro. Dissertação (Mestrado) - Programa de Pós-Graduação da Universidade de São Paulo, São Paulo, 2008. Mimeografado.

GINSBURG, Tom. Judicial review in new democracies: constitutional courts in Asian cases. Cambridge: Cambridge University Press, 2003.

GRIMM, Dieter. Constituição e política. Belo Horizonte: Del Rey, 2006.

Constitutions, constitutional courts and constitutional interpretation at the interface of law and politics. In: IANCU, Bogdan (Ed.). The law/politics distinction in contemporary public law adjudication. Utrecht: Eleven International Publishing, 2009.

Jurisdição constitucional e democracia, Revista de Direito do Estado, n. 3, Rio de Janeiro, jul./set. 2006.

HIRSCHL, Ran. The judicialization of politics. In: WHITTINGTON, Keith E.; KELEMEN, R. Daniel e CALDEIRA, Gregory A. (Eds.). The Oxford handbook of law and politics. Nova York: Oxford University Press, 2008.

The new constitutionalism and the judicialization of pure politics worldwide. Fordham Law Review, n. 75, Nova York, 2006-2007.

Towards juristocracy: the origins and consequences of the new constitutionalism. Cambridge: Harvard University Press, 2004.

HOLMES, Oliver Wendel. The path of the law. Harvard Law Review, n. 10, Cambridge, 1897.

ITALY: Effective resignation. Revista Time, $1^{\text {o }}$ out. 1956. Disponível em: <http://www.time.com/time/magazine/article/0,9171,862380,00.html>. Acesso em: 23 jan. 2010.

KENNEDY, Duncan. Legal education and the reproduction of hierarchy. Journal of Legal Education, n. 32, 1982.

KMIEC, Keenan D. The origin and current meanings of "judicial activism". California Law Review, n. 92, Berkeley, out. 2004.

KRAMER, Larry. The people themselves: popular constitutionalism and judicial review. Nova York: Oxford University Press, 2004.

LIMA, Martonio Mont'Alverne Barreto. Judicialização da política e comissões parlamentares de inquérito - um problema da teoria constitucional da democracia. Revista Jurídica da $\boldsymbol{F I C}$, n. 7, Fortaleza, jan./jun. 2006.

LLEWELLYN, Karl. Some realism about realism - responding to Dean Pound. Harvard Law Review, n. 44, Cambridge, 1931.

McMAHON, Christopher. Reasonable disagreement: a theory of political morality. Cambridge: Cambridge University Press, 2009. 
MENDONÇA, Eduardo Bastos de. A constitucionalização da política: entre o inevitável e o excessivo. Mimeografado.

A inserção da jurisdição constitucional na democracia: algum lugar entre o direito e a política, Revista de Direito do Estado, n. 13, Rio de Janeiro, jan./mar. 2009.

MIAILLE, Michel. Introdução crítica ao direito. 2. ed. Lisboa: Editorial Estampa, 1989.

MILES, Thomas J. e SUNSTEIN, Cass. The new legal realism. Public Law and Legal Theory Working Paper $n^{o}$ 191, Public Law and Theory Working Paper Series, University of Chicago Law School, 2007. Disponível em: <http://ssrn.com/abstract_id=1070283>. Acesso em: 16 ago. 2009.

MOREIRA NETO, Diogo de Figueiredo. Quatro paradigmas do direito administrativo pósmoderno. Belo Horizonte: Fórum, 2008.

MOREIRA, José Carlos Barbosa. Notas sobre alguns fatores extrajurídicos no julgamento colegiado. Caderno de Doutrina e Jurisprudência da Ematra XV, n. 3, Campinas, mai./jun. 2005.

NELSON, William E. The province of the Judiciary. John Marshall Law Review, n. 37, Chicago, 2004.

NEWTON, Jim. Justice for all: Earl Warren and the Nation he made. Nova York: Riverhead Books, 2006.

NOBLAT, Ricardo. Decisão do STF mantém monopólio dos Correios. Blog do Noblat. Disponível em: <http://oglobo.globo.com/pais/noblat/posts/2009/08/06/decisao-do-stfmantem-monopolio-dos-correios-211690.asp>. Acesso em: 6 ago. 2009.

Na íntegra, o bate-boca entre Joaquim Barbosa e Mendes. Blog do Noblat. Disponível em: <http://oglobo.globo.com/ pais/noblat/posts/2009/04/22/na-integra-bateboca-entre-joaquim-barbosa-mendes-179585.asp>.

O'CONNOR, Sandra. Public trust as a dimension of equal justice: some suggestions to increase public trust, The Supreme Court Review, n. 36, Chicago, 1999.

The majesty of the law: reflections of a Supreme Court Justice. Nova York: Random House, 2003.

PATRICK Devedjian: "Je souhaite que le Conseil constitutionnel soit à l'abri des soupçons". Le Monde, 12 jan. 2010. Disponível em: <http://www.lemonde.fr/politique/article/2010/01/12/m-devedjian-je-souhaite-que-leconseil-constitutionnel-soit-a-l-abri-des-soupcons_1290457_823448. html>.

PIRES, Thiago Magalhães. Crônicas do subdesenvolvimento: jurisdição constitucional e democracia no Brasil. Revista de Direito do Estado, Rio de Janeiro, n. 12, out./dez. 2009.

POGREBINSCHI, Thamy. Pragmatismo: teoria social e política. Rio de Janeiro: Relume Dumará, 2005.

POSNER, Richard. How judges think?. Cambridge: Harvard University Press, 2008.

Law, pragmatism and democracy. Cambridge: Harvard University Press, 2003.

POST, Robert. The Supreme Court opinion as institutional practice: dissent, legal scholarship and decisiomaking in the Taft Court. Minnesota Law Review, n. 85, Minneapolis, mai. 2001. 
e SIEGEL, Reva. Roe rage: democratic constitutionalism and backlash. Harvard Civil Rights-Civil Liberties Law Review, n. 42, Cambridge, jun. 2007.

RAWLS, John. Political liberalism. Nova York: Columbia University Press, 1996.

RECONDO, Felipe e GALLUCI, Mariângela. Caso Battisti expõe crise no STF. Estado de São Paulo. 22 nov.2009.

ROESLER, Shannon. Permutations of judicial Power: the new constitutionalism and the expansion of judicial authority. Law and Social Inquiry, n. 32, Hoboken, mai. 2007.

RORTY, Richard. Consequences of pragmatism. Minneapolis: University of Minnesota Press, 1982.

ROS, Luciano da. Tribunais como árbitros ou como instrumentos de oposição: uma tipologia a partir dos estudos recentes sobre judicialização da política com aplicação ao caso brasileiro contemporâneo. Direito, Estado e Sociedade, n. 31, Rio de Janeiro, dez. 2007.

RUGER, Theodore W.; KIM, Pauline T.; MARTIN, Andrew D. e QUINN, Kevin M. The Supreme Court Forecasting Project: legal and political science approaches to predicting Supreme Courte decisionmaking. Columbia Law Review, n. 104, Nova York, abr. 2004.

SADEK, Maria Tereza. Entrevista dada pela pesquisadora à revista eletrônica Consultor Jurídico. Disponível em: <http://www.conjur.com.br/2009-fev-08/entrevista-mariateresa-sadek-cientista-politica>. 8 fev. 2009.

Magistrados brasileiros: caracterização e opiniões. Disponível em: <http://www.amb.com.br/portal/docs/pesquisa/PesquisaAMB 2005.pdf>.

SANTISO, Carlos. Economic reform and judicial governance in Brazil: balancing independence with accountability. In: GLOPPEN, Siri; GARGARELLA, Roberto e SKAAR, Elin. Democratization and the judiciary. Londres: Frank Cass Publishers, 2004.

SARMENTO, Daniel. Interpretação constitucional, pré-compreensão e capacidades institucionais do intérprete. In: SOUZA NETO, Cláudio Pereira de; SARMENTO, Daniel e BINENBOJM, Gustavo (Coords.). Vinte anos da Constituição Federal de 1988. Rio de Janeiro: Lumen Juris, 2008.

SCHAUER, Frederick. Formalism: legal, constitutional, judicial. In: WHITTINGTON, Keith E.; KELEMEN, R. Daniel e CALDEIRA, Gregory A. (Eds.). The Oxford handbook of law and politics. Nova York: Oxford University Press, 2008.

SEGAL, Jeffrey A. e SPAETH, Harold J. The Supreme Court and the attitudinal model revisited. Cambridge: Cambridge University Press, 2002.

SIEDER, Rachel; SCHJOLDEN, Line e ANGELL, Alan. The judicialization of politics in Latin America. Nova York: Palgrave MacMillan, 2005.

SILVA, Alexandre Garrido da. Minimalismo, democracia e expertise: o Supremo Tribunal Federal diante de questões políticas e científicas complexas, Revista de Direito do Estado, n. 12, Rio de Janeiro, out./dez. 2008.

SOUZA NETO, Cláudio Pereira de. A interpretação constitucional contemporânea entre o construtivismo e o pragmatismo. In: MAIA, Antônio Cavalcanti; MELO, Carolina de Campos; CITTADINO, Gisele; e POGREBINSCHI, Thamy (Orgs.). Perspectivas atuais da filosofia do direito. Rio de Janeiro: Lumen Juris, 2005. 
STONE, Martin. Verbete "formalismo". In: COLEMAN, Jules e SHAPIRO, Scott (Eds.). The Oxford handbook of jurisprudence and philosophy of law. Nova York: Oxford University Press, 2002.

STRUCHINER, Noel. Posturas interpretativas e modelagem institucional: a dignidade (contingente) do formalismo jurídico. In: SARMENTO, Daniel (Coord.). Filosofia e teoria constitucional contemporânea. Rio de Janeiro: Lumen Juris, 2009.

SUNSTEIN, Cass e VERMEULLE, Adrian. Intepretation and institutions. Public Law and Legal Theory Working Paper No. 28. Public Law and Theory Working Paper Series, University of Chicago Law School, jul. 2002.

Radicals in robes: why extreme right-wing judges are wrong for America. Nova York: Basic Books, 2005.

. Tilting the scales rightward. New York Times. 26 abr. 2001.

; SCHKADE, David; ELLMAN, Lisa M. e SAWICKI, Andres. Are judges political? An empirical analysis of the Federal Judiciary. Washington: Brookings Institution Press, 2006.

SWEET, Alec Stone. Governing with judges: constitutional politics in Europe. Nova York: Oxford University Press, 2000.

TAMANAHA, Brian Z. Beyond the formalist-realist divide: the role of politics in judging. Princeton: Princeton University Press, 2010.

TATE, C. Neal e VALLINDER, Torbjörn (Eds.). The global expansion of judicial power. Nova York e Londres: New York University Press, 1995.

TERSMAN, Folke. Moral disagreement. Cambridge: Cambridge University Press, 2006.

THALER, Richard H. e SUNSTEIN, Cass R. Nudge: improving decisions about health, wealth, and happiness. $2^{\text {nd }}$ ed. Nova York: Penguin Books, 2009.

TROPER, Michel. Verbete "Interprétation". In: ALLAND, Denis e RIALS, Stéphane. Dictionnaire de la culture juridique. Paris: PUF, 2003.

TUSHNET, Mark. Critical legal studies: a political history. Yale Law Journal, n. 100, New Haven, mar. 1991. Press, 1999.

VANBERG, Georg. The politics of constitutional review in Germany. Cambridge: Cambridge University Press, 2005.

VANBERG, Georg. The politics of constitutional review in Germany. Cambridge: Cambridge University Press, 2005.

VERMEULE, Adrian. Foreword: system effects and the constitution. Harvard Law Review, n. 123, Cambridge, nov.2009-jun.2010.

VIANNA, Luiz Werneck; BURGOS, Marcelo Baumann e SALLES, Paula Martins. Dezessete anos de judicialização da política. Tempo Social, São Paulo, n. 19, nov. 2007.

; CARVALHO, Maria Alice Resende de; MELO, Manuel Palacios Cunha e BURGOS, Marcelo Baumann. A judicialização da politica e das relações sociais no Brasil. Rio de Janeiro: Revan, 1999. 
VIEIRA, José Ribas; CAMARGO, Margarida Maria Lacombe e SILVA, Alexandre Garrido. O Supremo Tribunal Federal como arquiteto institucional: a judicialização da política e o ativismo judicial. In: Anais do I Forum de Grupos de Pesquisa em direito Constitucional e Teoria dos direitos, Rio de Janeiro, 2009.

WALDRON, Jeremy. Law and disagreement. Oxford: Clarendon Press, 1999.

. Public reason and "justification" in the courtroom. Journal of Law, Philosophy and Culture, n.1, Lincoln, spring 2007.

The core of the case against judicial review. Yale Law Journal, n. 115, New Haven, abr. 2006.

WEEK IN REVIEW, New York Times, 12 jul. 2009. Disponível em: <http://www.gpoaccess.gov/congress/senate/judiciary/sh109-158/55-56.pdf>.

YEPES, Rodrigo Uprimny. Judicialization of politics in Colombia. International Journal on Human Rights, n. 6, Londres, 2007.

ZAGREBELSKY, Gustavo. El derecho dúctil: ley, derechos, justicia. 6. ed. Madri: Trotta, 2005. 